\title{
The Structure of Municipal Voting in Vancouver
}

\author{
June 23, 2022
}

\begin{abstract}
We offer a new interpretation of the structure of municipal electoral competition in Vancouver, focusing on the city's high-profile municipal election in 2018. Using novel "cast vote records" - a dataset containing each of the 176,450 ballots cast in the city's municipal election - we use a Bayesian multidimensional scaling procedure to estimate the location of every 2018 candidate and voter in Vancouver in a shared two-dimensional political space. We then use data from the Canadian Municipal Election Study (CMES), a large election survey undertaken in Vancouver in 2018, to interpret this political space, assessing 96 possible correlates of CMES respondents' locations in political space. We find evidence of a single primary dimension of competition, structured by left-right ideology, along with a secondary dimension dividing establishment from upstart parties of the right. Our paper supplies a new interpretation of Vancouver's electoral landscape, clarifies our understanding of the role of left-right ideology in municipal electoral competition, and demonstrates the promise of cast vote records for research on municipal elections and voting.
\end{abstract}

Keywords: Vancouver politics; municipal elections; urban politics; ideology; Bayesian estimation 


\section{Introduction}

Social scientists on the hunt for generalization often ignore the odd and idiosyncratic and in the world of city politics, there are few places more idiosyncratic than Vancouver. In most cities, voters choose their councillor from among a handful of competitors; in Vancouver, they select up to ten councillors from a cacophonous list of fifty or sixty names. In most cities, political parties are absent from local elections; in Vancouver, candidates compete in one of the most durable municipal party systems anywhere in the world. In most cities, especially in Canada, voters elect a council to oversee the bulk of the metropolis; in Vancouver, the elected council speaks for just a quarter of the metropolitan region. Other cities, like Calgary and Toronto, entice political scientists with their typical institutional structures and standard patterns of electoral competition. Vancouver, strange and exotic, enjoys much less attention.

Yet no one would deny that Vancouver is an important and often puzzling case. When many cities were moving back to single-member wards, Vancouver retained at-large competition. When local parties were fading into extinction in other cities, they surged back into vigorous life in Vancouver. Nestled inside Canada's third-largest metropolitan region, with a legacy of policy achievements that are the envy of many, Vancouver is one of North America's most interesting cities (Taylor 2019).

In this paper, we offer a new interpretation of the structure of municipal voting in Vancouver, focusing on the city's competitive and high-profile election in 2018. Using novel "cast vote records" - a dataset containing each of the 176,450 ballots cast in the city's municipal election - we use a Bayesian multidimensional scaling procedure to locate each Vancouver voter and candidate in a shared two-dimensional political space. To interpret this political space, we rely on data from the Canadian Municipal Election Study, a large survey of eligible voters in Vancouver in 2018. Because the survey includes municipal vote choices, we can measure each respondent's position in space alongside the cast vote records, and then interpret those spatial positions using detailed demographic, issue position, partisanship, and other data contained in the survey. We find strong evidence that municipal electoral competition in Vancouver is primarily structured by a 
single dimension related to ideology, issue positions, and partisanship. However, we also uncover a second dimension of political space related to voters' preferences for "establishment" versus "upstart" parties, which divides Vancouver's voters on the ideological right. This second dimension reflects emerging tensions in Vancouver's longstanding centre-right party, the Non-Partisan Association, and may also reflect a more general "united left, divided right" phenomenon that has been observed in the wider comparative politics literature.

Our principal purpose in this article is to provide a rigorous case study, using novel data and methods, of the structure of electoral politics in an important North American city. But our findings also have more general implications. We show that municipal voters can and do think about their vote choices in coherent and ideologically structured terms; despite some discussion about the collapse of the left-right divide in cities like Vancouver, we find strong evidence that much of Vancouver voting can be accounted for by a single left-right axis of competition. Our use of cast vote records - the first time, to our knowledge, that such data have been employed in a study of municipal elections - also provides a concrete methodological demonstration of the value of such data for urban politics scholarship, especially when researchers can combine them, as we do, with individual-level survey data.

\section{Municipal Elections in Vancouver}

Two institutions are at the centre of Vancouver's electoral distinctiveness: a municipal party system and at-large council elections. Each of these institutions has a history that stretches back nearly a century. Figure 1 summarizes this history by plotting party vote share in Vancouver elections from 1936, the first year that at-large elections were implemented, to the present] To simplify the presentation, we group political parties into four types: parties of the left, parties of the right (sometimes called "alphabet" parties because of their tendency to use acronym-style names, such as NPA or CGA),

\footnotetext{
${ }^{1}$ Vancouver had at-large elections in the 1920 s owing to a brief flirtation with a Single Transferable Vote electoral system, but this experiment was quickly abandoned. See Lucas (2020).
} 
urban reform parties, and other parties. Any remaining white space at the top of each bar is vote share received by independent candidates.

Within figure 1, we can discern four main phases of Vancouver's party system. In the first phase, which began in 1936 and continued until shortly after the end of the Second World War, Vancouver's municipal elections were battles between the Cooperative Commonwealth Federation (CCF) on the left and the Non-Partisan Association (NPA) on the right. As in other western Canadian cities, labour representatives sought positions on city council as part of a larger strategy of labour activism, and business leaders, frightened by the labour threat, mobilized to form "non-partisan" slates to oppose the labour candidates.2 While parties like the NPA regularly denied that they were "ideological", and even denied that they were political parties, political competition in this period had a recognizably left-right character ? $^{3}$ The NPA enjoyed consistent success during this first period, but labour representatives were also a consistent minority voice on city council (Tennant 1980).

The second phase, which stretched from the mid-1950s to the mid-1960s, was a period of single-party dominance - what Trounstine (2008) has called "political monopoly" - by the Non-Partisan Association. Canny moves by the NPA to incorporate moderate labour candidates into their party, together with an increasingly fractured labour movement, gave the NPA consistent and dominant majorities on city council. Here, too, Vancouver's party system development resembled similar patterns in other western Canadian cities, such as Calgary and Winnipeg, and like those cities, a growing share of the vote in this period went to candidates with no party affiliation. By the 1960s, party-affiliated candidates in Vancouver regularly received fewer than half of the votes in municipal elections, and what had once been a system of vigorous party competition appeared to be headed toward extinction.

In the gradual decline of its party system, first by single-party dominance and then the rise of independent candidates, Vancouver closely resembled other large western Cana-

\footnotetext{
${ }^{2}$ For a survey of this history in Vancouver, see Gutstein (1983), Madden (2003), and Tennant (1980). For Calgary, see Bright (1998); for Winnipeg, see Epp-Koop (2015).

${ }^{3}$ For analogues in the United States, see Bridges (1999) and Trounstine (2008).
} 


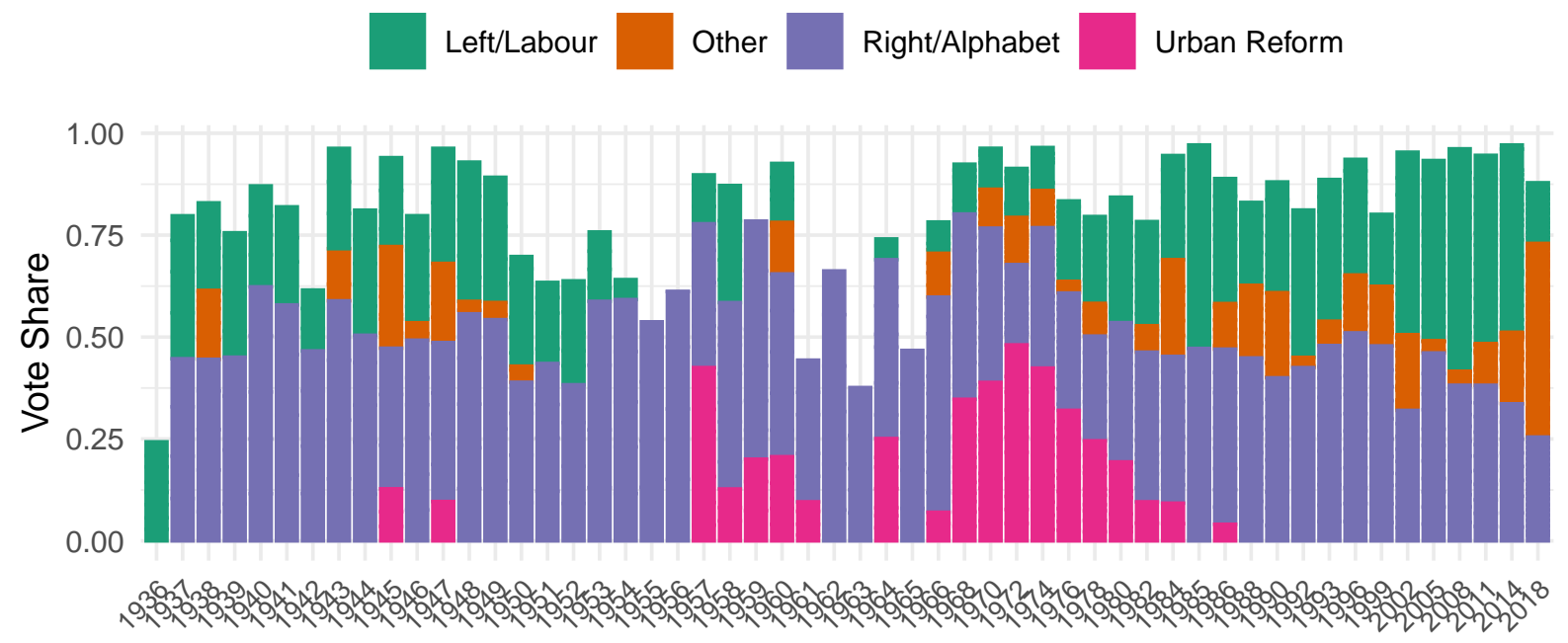

Figure 1: Overview of Vote Share by Party in Vancouver, 1936-Present

Note: White space above bars represents vote share for independent candidates.

dian cities (Lucas 2021). In Vancouver, however, the rise of a vibrant middle-class urban reform party, The Electors Action Movement (TEAM), sparked a highly distinctive resurgence of party competition in the late 1960s and early 1970s. In this third phase, political competition focused on characteristic "urban reform" issues, such as freeway construction, neighbourhood protection, and urban "livability", few of which could be easily characterized as standard left-right disagreements. ${ }^{4}$ While TEAM faded as a major force in Vancouver politics by the early 1980s, it helped to rejuvenate the city's party system, setting the city on a course completely unlike other Canadian cities (Tennant 1980).

Around the same time that TEAM was born, a new party of the left, the Coalition of Progressive Electors (COPE), had also emerged, and by the 1980s, COPE had grown into an impressive force in the city's elections. While the exact configuration of political parties has varied widely since then, the basic structure of the system - a thoroughly partisan environment grounded in competition between a party of the right (NPA) and an evolving array of parties on the left - has persisted (Vogel 2003). The result, since the 1980s, has been a robust municipal party system quite unlike any other city in Canada, and perhaps unlike any city in the Anglo-American world 5

\footnotetext{
${ }^{4}$ See Magnusson (1983a) and Magnusson (1983b) for a persuasive argument about the essentially conservative character of the Canadian urban reform movement during this period. See DeLeon (1992) for a related discussion of the internal complexities of the urban left.

${ }^{5}$ In one other Canadian province, Quebec, candidates in big-city elections also compete as members
} 


\subsection{The 2018 Election in Vancouver}

By 2018, many observers of Vancouver's municipal politics had come to think that the city's party system, and its longstanding pattern of left-right party competition, was beginning to come unglued. The housing affordability issue, which had reached crisis levels in Vancouver, was thought to have fractured traditional patterns of electoral competition on both the left and the right. On the right, internal disputes within the Non-Partisan Association led to a new pro-development party, YES Vancouver, as well as a self-described "populist party" called Coalition Vancouver. The proximate cause of the two new parties was intra-partisan resentment among two candidates - Hector Bremner, founder of YES Vancouver, and Wai Young, founder of Coalition Vancouver - whose interest in seeking the NPA's mayoral nomination had been informally discouraged (Young) or formally rejected (Bremner). Beneath the personal slights, however, were deeper tensions about the appropriate position of a centre-right party in one of Canada's most progressive cities: YES Vancouver embracing a market-friendly, pro-development platform in the name housing affordability; Coalition Vancouver embracing a car-friendly populist agenda; and the Non-Partisan Association advocating an establishment-friendly platform of fiscal prudence and modest intensification.

On the left, partisan wrangling in early 2018 was equally fraught. A council byelection in 2017 in which an NPA candidate had won with $28 \%$ vote share, benefiting from a vote split among four progressive candidates, sparked fears of a similar outcome in the 2018 election $]^{6}$ As a result, the Vancouver and District Labour Council, long an important player in Vancouver civic politics, sought to coordinate the city's four progressive parties - Green, Vision Vancouver, COPE, and OneCity - to select a congenial mayoral candidate and coordinate an optimal slate of candidates for the at-large council, park board, and school board races. Coordination on a mayoral candidate soon fell apart - after incumbent Gregor Robertson said he would not run, the temptation of an open

of political parties. In Quebec, however, parties are typically built around mayoral candidates - "Équipe Denis Coderre", "Équipe Labeaume", and so on - making the party system much less durable than in Vancouver. Nowhere else in Canada do we find parties like NPA or COPE: durable parties with long histories, recognizable coalitions of support, and consistent policy agendas.

${ }^{6}$ See Vancouver Province 2018-02-14, A4; Vancouver Sun 2018-03-24, A3. 
race proved too great to resist, and several high-profile progressives entered the contests - but negotiations were more successful for the at-large contests, and the parties agreed to limit their slates to prevent mutually destructive vote-splitting $]^{7}$ Even for the at-large races, however, coordination was far from perfect; the Green Party, emboldened by strong results in local polls, abandoned its initial pledge and chose to run more candidates for council than it had promised $\$^{8}$

By the time of the 2018 election, Vancouver voters faced a dizzying array of options - some 21 mayoral candidates and 71 council candidates. To make sense of this complex ecology of candidates and parties, some local observers suggested that a second axis of political disagreement, which Allen Pike (2018) described as an "urbanist-conservationist" dimension, had emerged in Vancouver. Along this new axis, Vancouver's parties could be distinguished by their interest in preserving the city's existing development (conservationism) versus aggressive new housing construction, densification, and active transportation (urbanism) 9 $^{9}$ A crowd-sourced survey by Ian Bushfield and Stewart Prest, which asked participants to score parties on several policy dimensions, provided apparent support for the two-dimensional structure that Pike described (Bushfield and Prest 2018).

Table 1: Overview: Municipal Parties in Vancouver

\begin{tabular}{|c|c|c|c|c|}
\hline Party Name & Entry & $\begin{array}{l}2014 \\
\text { Council }\end{array}$ & $\begin{array}{l}2018 \\
\text { Council }\end{array}$ & Description \\
\hline Non-Partisan Association & 1936 & 3 & 5 & $\begin{array}{l}\text { Longstanding party formed in 1930s as alternative to } \\
\text { pro-labour CCF party. }\end{array}$ \\
\hline Coalition of Progressive Electors & 1968 & 0 & 1 & $\begin{array}{l}\text { Explicitly progressive party formed in second wave of } \\
\text { urban reform period. }\end{array}$ \\
\hline Green Party of Vancouver & 1984 & 1 & 1 & $\begin{array}{l}\text { Municipal party affiliated with provincial and federal } \\
\text { Green Party in Canada. }\end{array}$ \\
\hline Vision Vancouver & 2005 & 7 & 0 & $\begin{array}{l}\text { Breakaway from COPE in } 2005 \text {, intended as a more } \\
\text { moderate and 'electable' party. }\end{array}$ \\
\hline OneCity & 2014 & 0 & 1 & $\begin{array}{l}\text { Formed in } 2014 \text { by former COPE members due to } \\
\text { personal and strategic disagreements. }\end{array}$ \\
\hline Vancouver 1st & 2014 & 0 & 0 & $\begin{array}{l}\text { Created in } 2014 \text { as a 'big tent' party, but unsuccessful in } \\
2014 \text { and } 2018 \text {. }\end{array}$ \\
\hline Coalition Vancouver & 2018 & $\mathrm{~N} / \mathrm{A}$ & 0 & $\begin{array}{l}\text { Breakaway from NPA after Wai Young's NPA mayoral } \\
\text { candidacy discouraged by NPA board. }\end{array}$ \\
\hline Yes Vancouver & 2018 & $\mathrm{~N} / \mathrm{A}$ & 0 & $\begin{array}{l}\text { Breakaway from NPA after Hector Bremner's NPA } \\
\text { mayoral candidacy denied by NPA board. }\end{array}$ \\
\hline ProVancouver & 2018 & $\mathrm{~N} / \mathrm{A}$ & 0 & Minor party formed to contest 2018 municipal races. \\
\hline
\end{tabular}

\footnotetext{
${ }^{7}$ See Vancouver Sun 2018-03-17, A6; Globe and Mail 2018-03-26, A8; The Province 2018-05-09 A6; The Province 2018-06-05 A10.

${ }^{8}$ Vancouver Sun 2018-07-03 A1.

${ }^{9}$ These discussions bear some resemblance to recent work on the structure of ideological disagreement in municipal politics; see, for example, Cann (2018) and Bucchianeri et al. (2021).
} 
In the end, however, the 2018 election proved more evolution than revolution. In the mayoral race, Kennedy Stewart, a former NDP Member of Parliament, narrowly defeated Ken Sim, the Non-Partisan Association's candidate. In the at-large races, each of the progressive parties had some success, with the exception of the incumbent party, Vision Vancouver, which was shut out of both the council and the park board. Despite the pre-election drama, neither YES Vancouver nor Coalition Vancouver performed well, and the Non-Partisan Association remained the only centre-right party with representation in any of local offices. Vancouver's 2018 municipal election thus serves nicely as a case study of more general dynamics in the city's party system and electoral competition since the emergence of its modern party system, and developments in Vancouver since 2018, including the ongoing fracturing of the city's party system on the right, suggest that it is valuable for interpreting future elections in Vancouver as well.

\subsection{The Structure of Municipal Elections}

However distinctive Vancouver's institutions and party system may be, local discussions about the structure of political competition in Vancouver bear a striking resemblance to broader debates about the character of municipal elections, and especially the role of left-right ideology as an organizing principle of local politics. One aspect of this debate concerns the character and dimensionality of municipal policy attitudes themselves; after all, if municipal policy attitudes are not meaningfully structured by ideology, it would be unlikely that ideology would serve as an organizing principle of municipal competition 10 Some have argued that it is appropriate, at least in the United States, to characterize municipal ideology along a standard, unidimensional left-right axis (Tausanovitch and Warshaw 2013, 2014); Lucas and Armstrong II (2021) have made a similar argument in Canada, demonstrating that municipal residents' general left-right policy attitudes are strongly related to their elected representatives' left-right positions on specifically municipal issues. However, others have argued that municipal policy attitudes are more

\footnotetext{
${ }^{10}$ Of course, in conditions of extremely nationalized politics, the absence of ideological structure for municipal issues would not prevent ideological structure for municipal political competition. We will argue below that municipal issues in Vancouver appear to sit comfortably within larger left-right debates. See Hopkins (2018) for a detailed treatment of the nationalization issue.
} 
idiosyncratic (Oliver 2012), focused on geographically specific interests and interest group activity (Anzia 2021), or, alternatively, that they are structured by a second dimension of disagreement primarily related to the role of the market in local land use policy (Bucchianeri et al. 2021; Cann 2018). The general structure of municipal policy disagreement, and the relationship between local policy attitudes and ideological disagreement at other levels of government, remains a subject of active debate (DeLeon 1992; Hopkins 2018; Anzia 2021).

In the more specific context of municipal electoral politics, a large body of research has found that standard ideological and partisan positions are clearly relevant to municipal vote choice in Canada and the United States (Holman and Lay 2021; Lucas 2022; Lucas and McGregor 2020; Sances 2018), but other factors, such as race (Hajnal and Trounstine 2014; Kaufmann 2004) and local policy issues (Oliver and Ha 2007) also affect municipal voting. Two excellent studies of mayoral voting in Vancouver, covering the 2002 and 2018 elections, have argued that ideology and policy issue attitudes were crucial predictors of mayoral vote choice (Cutler and Matthews 2005a; Rooij, Matthews, and Pickup 2020), though it is not yet clear if these findings apply to non-mayoral voting decisions. Thus, together with other case studies of municipal voting behaviour and policy making (Boudreau, Elmendorf, and MacKenzie 2015; Bucchianeri 2018; Burnett 2019; Holman and Lay 2020), our assessment of the structure of municipal voting in Vancouver has broader relevance as well - and, as we will argue below, primarily supports a single-dimensional and ideologically structured interpretation of municipal voting behaviour.

In the analysis below, we extend past research on the structure of municipal competition in at least three ways. First, we use cast vote records to build our interpretation of Vancouver's electoral competition from observed votes themselves - and the similarities and differences among voters that these votes imply - rather than survey-based measures. Like studies of legislative roll call voting in the United States (Poole and Rosenthal 1997) and Canada (Godbout 2020), our analysis of Vancouver's cast vote records allows us to begin by estimating the unique sources of variation that structure electoral competition 
from observed votes and then use additional data to interpret that structure.

Second, our analysis builds on past research by estimating each voter's spatial location using a summary of many votes cast in Vancouver's municipal election. For all that we have learned from excellent municipal election studies in Canada and the United States, the overwhelming majority of those studies have focused on mayoral vote choice, and mayoral elections may be quite distinctive relative to lower-information contests for municipal council and elected special purpose bodies (Oliver 2012). Our analysis allows us to incorporate these important "down-ballot" elections into a more general interpretation of municipal electoral competition, one that includes competition for council and an elected special-purpose board. While mayoral elections lend themselves well to standard regression-based models of vote choice, understanding the structure of municipal voters' choices across many local offices is more complex, and requires that we develop methods to identify the underlying sources of variation that may exist across the many choices that voters make in at-large municipal elections. In these cases, standard regression models are often infeasible. In the case of Vancouver's city council, for instance, we would need a model that was a mix between a binomial model (where respondents make $k$ choices out of $n$ possible options) and a multinomial model where we identify exactly which choices those were across some 71 distinct candidates. Further, we are often interested in understanding the underlying structure of voters' decisions more than their decision to vote for any one candidate in particular. Our analysis offers an example of such an approach for an especially complex municipal electoral system.

Finally, we extend past research by combining our measure from the cast vote records with the most extensive individual-level survey of eligible voters ever undertaken in Vancouver. Because our survey data include each respondent's choices for mayor, council, and park board, we can measure survey respondents' spatial positions on exactly the same scale as the actual voters in the cast vote records 11 We then interpret those positions using nearly 100 election-related CMES variables including ideology, partisanship, retrospection, place identity, and policy issue attitudes. This allows to measure and visualize

\footnotetext{
${ }^{11}$ As we explain below, we do not include school board votes in our measure, because we lack school board votes in the CMES survey data.
} 
the structure of electoral competition in Vancouver and then interpret that structure using a rich suite of relevant individual-level predictors.

\section{Data and Methods}

To measure and interpret the structure of municipal voting in Vancouver, we rely on two data sources. The first is the "anonymized ballot marking" dataset provided by the City of Vancouver ${ }^{12}$ This dataset is an example of an emerging data format called "cast vote records" (CVR), which provide an anonymized record of the full population of ballots cast in an election. In Vancouver, for example, the dataset provides complete information on the mayor, council, park board, school board, and plebiscite votes cast on each of the 176,450 ballots in the 2018 municipal election. We measure Vancouver voters' spatial locations using their council and park board votes, the two multi-member races for which we also have data for our survey respondents.

While CVR data are new to Canadian politics, several studies in the United States have made use of these data to explore political representation (Gerber and Kollman 2004), split-ticket voting and partisanship (Agadjanian and Robinson 2019; Kuriwaki 2019), and to understand the outcomes of unusual or especially close elections (Herron and Lewis 2007; Bafumi et al. 2012). Some of these analyses have employed IRT models (Herron and Lewis 2007) to explore latent patterns in the data, and Shiro Kuriwaki, a leading scholar in the collection and use of CVR data in the United States, has proposed a measurement approach for CVR data that enables clearer understanding of split-ticket voting (Kuriwaki 2019). We build on this research in two ways. First, we introduce Bayesian multidimensional scaling as a practical measurement approach for CVR data; we explain this approach in more detail below. Second, as we noted above, we measure our election survey respondents' spatial positions alongside the vote choices in the CVR data, allowing us to combine the strengths of CVR and survey data. We hope that both of these advances will be useful for other researchers, particularly as both CVR data

\footnotetext{
${ }^{12}$ This dataset is available on the city's open data platform at this link: https://opendata.vancouver.ca/explore/dataset/anonymous-ballot-marking/information/
} 
and large-N surveys become available at all levels of government, including municipal elections.

Some readers may wonder why we use CVR data at all - after all, if we have mayor, council, and park board vote choices available in our survey dataset, why not simply use the survey data to measure each respondent's location in political space? While there are several advantages to using the full population of votes, the most important has to do with the ability to estimate spatial locations for every voter regardless of their exact combination of votes - including voters with idiosyncratic voting patterns. As Herron and Lewis (2007) point out, survey data are often unhelpful when researchers are interested in uncommon vote choices or vote combinations. In Vancouver, more than 100,000 distinct combinations of mayor, council, and park board votes were cast in the 2018 election, of which some 88,000 were unique to a single voter. Each of these combinations helps to reveal more general patterns of similarity and difference among candidates and voters, and the full CVR dataset enables us to measure voters' spatial positions even when they support candidates who received few votes - candidates whose supporters would be unlikely to appear in any numbers in survey data.

\subsection{Survey Data}

Our Bayesian multidimensional scaling procedure enables us to identify the unique sources of variation that run through the complex, multidimensional cast vote records dataset. This lower-dimensional structure, if it exists, could arise from a variety of possible sources: as we noted above, urban scholars have pointed to a wide variety of bases for municipal electoral competition, including geographic divides, racial and ethnic cleavages, distinctions between homeowners and renters, and ideological disagreement. Thus, to interpret the structure of the latent space that our multidimensional scaling procedure recovers, we turn to the Canadian Municipal Election Study (CMES) Vancouver survey. The Canadian Municipal Election Study project is a comparative study of eight big-city elections in Canada in 2017 and 2018, and includes 1,642 responses from Vancouver (McGregor et al. 2021). The Vancouver CMES survey was a two-wave panel survey consisting of 
a pre-election wave $(\mathrm{N}=1,642)$ collected between September 28 and October 20, 2018, and a post-election wave $(\mathrm{N}=903)$ collected between October 22 and November 21, 2018. Respondents were recruited by Forum Research using a mix of random digit dial (N=999) and online panel $(\mathrm{N}=643)$ recruitment. Having agreed to participate, respondents then completed the survey instrument online. Because we are interested in the structure of municipal voting in Vancouver, we focus here on the post-election survey respondents who voted in the 2018 municipal election $(\mathrm{N}=660)$.

The Canadian Municipal Election Study was conceived as an omnibus comparative election survey, akin to well-known national election studies, and thus includes a wide range of questions on vote choice, attitudes, and behaviour. In Vancouver, the CMES post-election survey included questions on respondents' vote choices for mayor, council, and park board elections, which allow us to measure CMES respondents' spatial positions within the same measurement model as the voters in the CVR dataset.

Because our goal is to use the CMES data to help interpret the spatial structure that we recover from the CVR analysis, we cast a wide net in selecting CMES variables for our exploratory analysis. This allows us to understand how a wide range of attitudes, behaviours, and identities relate (or do not relate) to the main dimensions of political competition in Vancouver. We selected a total of 96 variables for our exploratory analysis, which we organize into nine general "families" ${ }^{13}$ We note, however, that we use these "families" only for the purposes of organization and visualization rather than analysis.

Our first family of variables consists of socio-demographic items. While the general importance of socio-demographic predictors for vote choice in Canada and elsewhere remains an important area of research, urban political scientists have long emphasized the role of these variables in municipal politics, with a particular focus on race (Hajnal and Trounstine 2014; Kaufmann 2004) and home-ownership (Fischel 2005; Mcgregor and Spicer 2016). Past studies in Vancouver have found that gender, age, income, and homeownership were informative predictors of mayoral vote choice in 2018 (Rooij, Matthews,

\footnotetext{
${ }^{13}$ Note that these variables are used only in the second, interpretive analysis. The first stage measurement model is based exclusively on recorded vote choices in the CVR and CMES data. In other words, we do not use CMES respondents' positions on these 96 variables to measure their latent spatial positions, but rather to interpret those positions having estimated them using vote choices alone.
} 
and Pickup 2020). We include each of these variables in our analysis below.

A second family of variables captures respondents' place identity and civic pride at the neighbourhood, city, provincial, and federal scales. These variables have been employed in studies of vote choice and policy attitudes in Canada and the United States (Gimpel et al. 2019; Kal Munis 2021; Wong 2010), and recent research in Canada has suggested that place identity may be related to municipal political participation and policy attitudes (Borwein and Lucas 2021).

We also include a family of variables related to respondents' knowledge of, interest in, and attention to politics at both the municipal and provincial/federal scales. Past research in other Canadian cities has found that knowledge and attention are related to incumbent vote choice (Moore, McGregor, and Stephenson 2017). Individuals' interest and attention may also be associated with their electoral preferences, and thus their spatial position, in Vancouver's municipal elections as well.

Retrospective voting is an especially well-established predictor of individual voting behaviour, including at the municipal scale (Anderson et al. 2015; Hopkins and Pettingill 2018). We include a suite of variables related to respondents' satisfaction with their mayor and councillors' performance in office, as well as assessments of the direction of the local economy over the past year. We also include variables that capture respondents' feelings toward, and ideological placements of, mayoral candidates in the 2018 election, along with a series of feeling thermometer measures of respondents' feelings toward social groups. These are not only related to individuals' ideological positions but may also play a role in political behaviour and politically salient social identities (Wong 2010).

Our three remaining "families" of variables are the factors that we expected to be most valuable for interpreting the structure of municipal voting in Vancouver. Partisanship is a well-known predictor of municipal vote choice, even in non-partisan elections, and past research on mayoral vote choice in Vancouver (Cutler and Matthews 2005b) and other Canadian cities (Lucas and Santos 2021; Stephenson, McGregor, and Moore 2018) has found that individuals' provincial and federal partisanship often predicts their support for mayoral candidates even when those candidates are not explicitly aligned with a 
provincial or federal party. In Vancouver, the candidate who became mayor, Kennedy Stewart, had been a Member of Parliament for the New Democratic Party, and some speculated that the divide between Stewart and Shauna Sylvester, his main progressive competitor, was partly a contest between those who supported the federal NDP and those who supported the federal Liberals (Bula 2018). We thus have good reason to explore the role of provincial and federal partisanship in municipal voting behaviour in Vancouver.

Given the extraordinary emphasis on housing and affordability in the 2018 election, along with the role of housing in the "urbanist-conservationist" axis discussed above, we also have good reason to explore the role of policy issues in Vancouver's municipal voting. CMES data include questions on the importance of six issues, including homelessness and housing affordability, as well as issue position questions concerning the gender and racial composition of council, immigration policy, and the role of government in home prices. These questions are particularly valuable for assessing whether a second dimension of electoral competition was distinctively structured by disagreement related to housing, land use planning, and affordability.

Finally, we are especially interested in the role of ideology in Vancouver's municipal elections. We know from past research in Vancouver that ideology is an important factor for mayoral vote choice (Rooij, Matthews, and Pickup 2020), and more general research on Canadian municipal politics has shown that ideology plays a role in municipal political representation (Lucas 2022; Lucas and Armstrong II 2021) and voting behaviour (Lucas and McGregor 2020). We strongly suspected that the same would be true in Vancouverin fact, we suspected that the two-dimensional competition discussed by close observers may have been perceived by ordinary voters as a more unidimensional left-right axis. To assess these possibilities, we use respondents' ideological self-placement, as well as a latent measure of their policy ideology, in our exploratory analysis below ${ }^{14}$ These variables - especially the latent policy ideology measure - help move beyond measures of local ideology that are based on variables from other levels of government (such as

\footnotetext{
${ }^{14}$ To measure respondents' latent policy ideology, we combine fourteen issue importance and issue position questions (all of which load strongly on a single dimension in a standard factor analysis) and measure respondents' latent policy ideology using a Bayesian factor analysis model.
} 
partisanship) as well as ideological scores that have not been generated from voters' specifically municipal policy positions (Anzia 2021; Schaffner, Rhodes, and La Raja 2020). Unlike many past measures, the content of CMES respondents' positions on the latent policy ideology measure, at least, reflects their left-right position on specifically municipal policy issues in Vancouver.

\subsection{Measurement and Modeling}

Vancouver's anonymized ballot marking data provides us with a complete record of municipal votes in the 2018 municipal elections. We can conceptualize these ballot records as providing a picture of the spatial structure of the election, with voters whose ballots are similar to one another being "closer" in some multidimensional space, and voters with very dissimilar ballots being more "distant" in that space. Our measurement challenge is to reduce this extremely complex multidimensional space into a more readily interpretable two-dimensional picture while preserving, as much as possible, the original distances among voters and the candidates they support.

To carry out this measurement task, we employ a multidimensional scaling technique called unfolding (Armstrong et al. 2021). The idea behind this method is that we can conceive of the main axes of competition (two in this case) as defining a plane. Further, we could place both voters and candidates as points on this plane. To do so, we position them in such a way that the candidates' points are spatially proximate to the voters who chose them, and more distant from voters who chose other candidates. More formally,

$$
\operatorname{Pr}\left(v_{i j}=1\right)=f\left(d_{i j}\right)
$$

where $v_{i j}$ is a binary indicator of individual $i$ 's vote for party $j$. Further, $d_{i j}=$ $\sqrt{\left(x_{i 1}-y_{j 1}\right)^{2}+\left(x_{i 2}-y_{j 2}\right)^{2}}$, the Euclidean distance between voter $i$ 's position $\left(x_{i} k\right)$ and candidate $j$ 's position $\left(y_{j} k\right)$ across each of the $k$ dimensions. The probability of voting for a candidate is a decreasing function $f(\cdot)$ of distance. That is, the closer a candidate is to a voter, the more likely the voter is to choose that candidate.

We estimate the $x$ and $y$ points with a Bayesian model. We specify $f($.$) as the CDF of$ 
the logistic distribution, making this essentially a logistic regression of vote choice based on distance. We use standard normal priors for the ideal points of both candidates and voters. The voter ideal points are standardized to have zero mean and unit variance in each posterior draw. This identifies the scale of the ideal points. We identify the direction of the scale with a post-estimation rotation of the two-dimensional space to maximize the interpretability of the results ${ }^{15}$

We characterize the posterior distribution of the parameters using Automatic Differentiation Variational Inference (ADVI) (Kucukelbir et al. 2017). This is much more computationally efficient than Gibbs sampling, which approximates the multivariate posterior with draws from the marginal distribution of each parameter, or Metropolis-Hastings, which draws from the full multivariate posterior. Variational inference tries to find a more tractable approximation of the posterior distribution. Again, for computational efficiency, we use a mean field approximation, which assumes the posterior distribution is well-approximated by independent normal distributions. This is generally not problematic for uni-dimensional measurement models because all parameters are assumed to be independent in the theoretical model. These properties should extend to $k$-dimensional settings as well.

We use the PyMC3 library (Salvatier, Wiecki, and Fonnesbeck 2016; Martin 2018) in Python to estimate the model. We run the ADVI algorithm for 50,000 iterations, at which point the loss function appeared to have flattened out, indicating that an appropriate approximation had been reached. We are encouraged by the general similarity between the Bayesian results and those from frequentist unfolding methods.

We focus on two dimensions in this measurement model for three reasons. The first and most important is theoretical: as we noted above, theoretical debates about the latent structure of municipal policy attitudes and voting behaviour in municipal politics

\footnotetext{
${ }^{15}$ More specifically, we rotate the raw results by 30 degrees to capture the ideological structure of the first dimension of competition. Note that this rotation changes nothing about the distances between the points, it simply aligns the major axis of competition (ideology) with the horizontal axis of the graph to enhance interpretability.

${ }^{16}$ For example, comparing results from our Bayesian procedure with a frequentist multidimensional scaling procedure using an optimization approach known as stress majorization, we find that our first dimension placements are correlated at $\mathrm{r}=0.93$, and the second dimension placements are correlated at $\mathrm{r}=0.79$.
} 
in general, and in Vancouver in particular, have consistently focused on two issues: the character of the first dimension of disagreement or competition (whether it is animated by ideology and partisanship, race, geography, etc.) and the presence of a second dimension. These debates are themselves grounded in a much larger literature that explores the character of mass and elite policy preferences and voting behaviour (Caughey, O'Grady, and Warshaw 2019; Jessee 2012; Tausanovitch and Warshaw 2013). We thus have good theoretical reason to explore the presence and character of Vancouver voters' choices in two dimensions of latent space, and little theoretical reason to push into additional dimensions.

The second motivation for our two-dimensional measure is empirical: as we will explain below, our second dimension is important primarily for understanding the choices of Vancouver voters on the ideological right, and provides very little additional information about the choices of voters on the ideological left. Because the second dimension is primarily relevant to just one subset of the larger population, it is likely that further dimensions would merely differentiate among ever-smaller subsets, rather than provide information about Vancouver voters in general.

Finally, given that our measurement model includes more than 176,000 voters (as well as the Canadian Municipal Election Study respondents), there are serious computational constraints involved in moving to higher-dimensional solutions. Even with our more efficient ADVI implementation, our two-dimensional measurement model requires about 36 hours to execute, and higher-dimensional solutions would be likely to dramatically increase this completion time. Given our theoretical and empirical reasons for focusing on a two-dimensional measurement model, these computational constraints are an additional reason to focus our attention on two dimensions.

\section{Results}

We begin with figure 2, which summarizes the spatial locations of candidates and parties in Vancouver's 2018 election. In the top panel, we plot the two-dimensional location of 
each council and park board candidate (the small circles) as well as the average location of each party (the larger circles, sized by number of votes received). To enable easier party-by-party comparisons, we also provide separate plots of mean party locations for each dimension in the two bottom panels.

These results provide a valuable overall picture of the structure of electoral competition in Vancouver in 2018. The first dimension is recognizably ideological: a cluster of progressive parties on the left (OneCity, COPE, Vision Vancouver, Green), and more conservative parties on the right (Non-Partisan Association, YES Vancouver, Vancouver 1st, Coalition Vancouver). On the right, the first-dimension spatial locations align well with contemporary descriptions of the parties, with Coalition Vancouver as the most conservative, YES Vancouver in a more moderate position, and the NPA between the two. On the left, the spatial arrangement is similarly intuitive, with OneCity and COPE to the left of the more moderate Greens. Vision Vancouver's position at the leftward end of the scale is somewhat curious - recall that Vision Vancouver was originally created as a moderate alternative to COPE - but may reflect the fact that the party's 2018 slate was notably more youthful and progressive than would have been typical in previous election cycles. Still, if we zoom out from the specific placements and focus on the first dimension as a whole, it is quite clear that party locations reflect a recognizable left-right structure. As we will soon see, this interpretation is well supported by the individual-level CMES data.

The second dimension in figure 2 is equally straightforward to interpret, clearly capturing a divide between established and upstart parties of the right. At one pole is the Non-Partisan Association, the city's oldest political party. At the other pole are the new parties of the right, two of which (Coalition Vancouver and YES Vancouver) were contesting elections for the first time in 2018. Among these upstart parties, YES Vancouver and Vancouver 1st are closer to one another, which reflects those parties' shared emphasis on a socially moderate, pro-business, pro-development policy agenda. Coalition Vancouver, whose campaign came to be associated with a populist, pro-automobile, anti-bike-lane platform, is more distant. Importantly, we observe no difference on the second dimension 


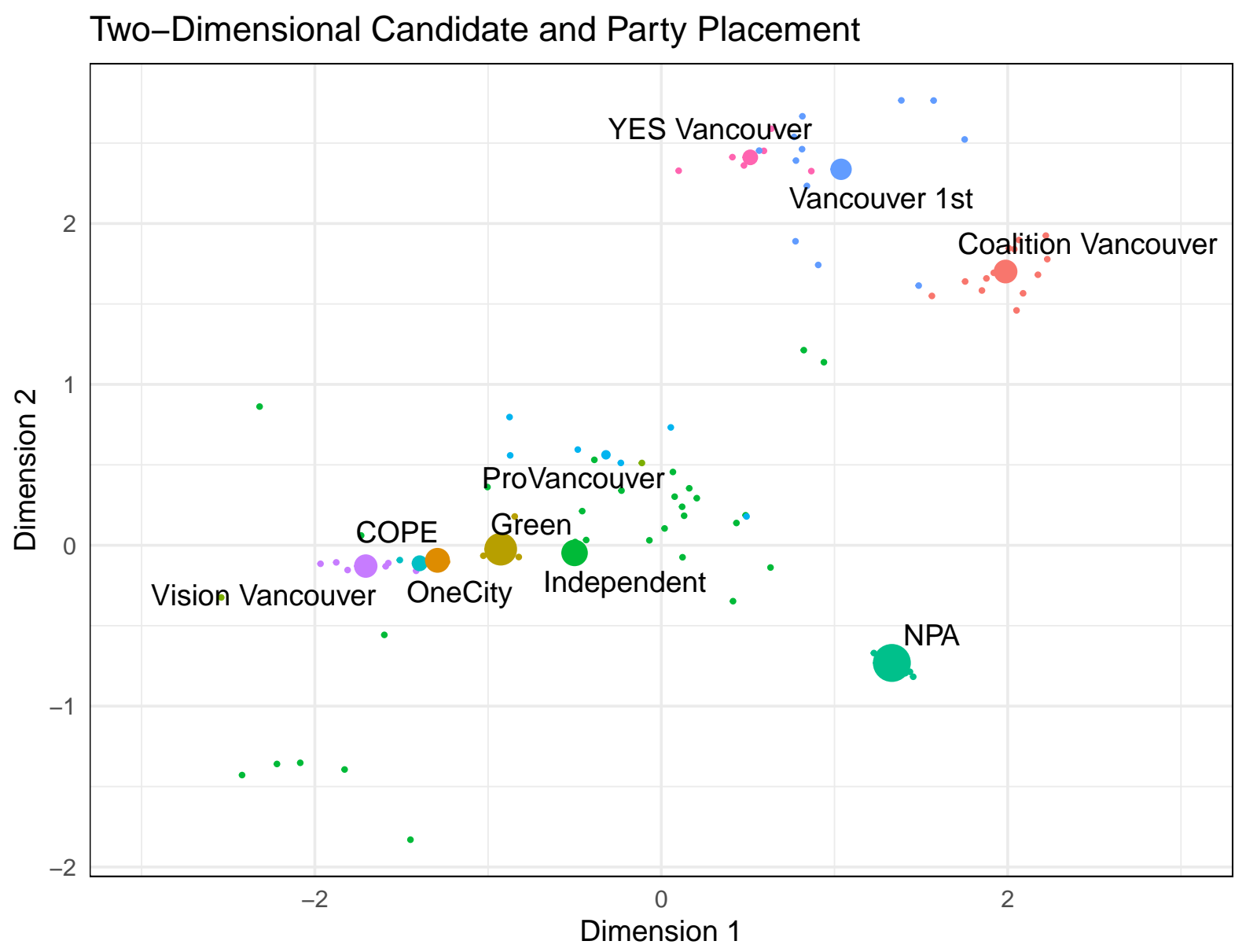

First Dimension, by Party

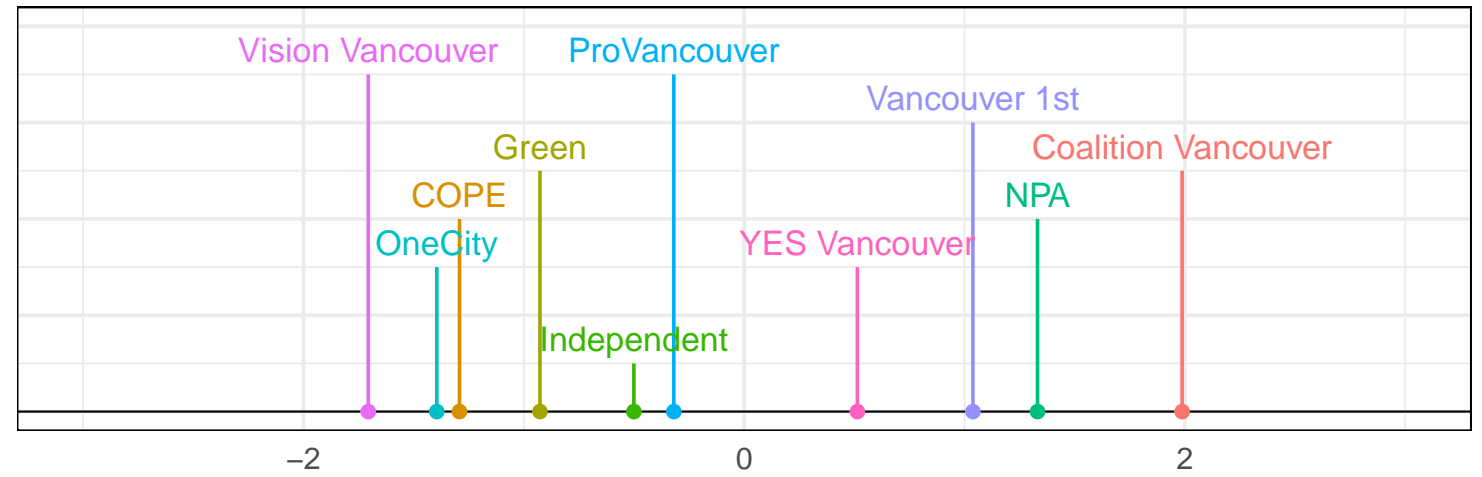

Second Dimension, by Party

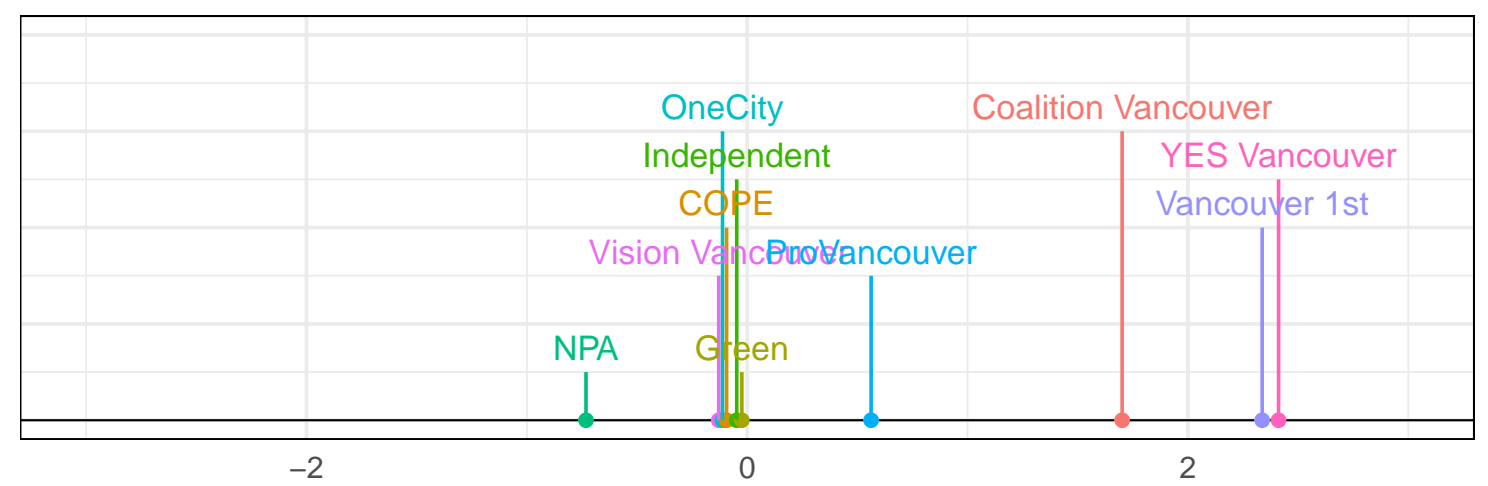

Figure 2: Spatial Location of Candidates and Parties in Vancouver 
among any of the city's four progressive parties, all of whom are positioned in a mutually indistinguishable middle position. Whatever it is that animates the second dimension of competition, in other words, it is not especially relevant to understanding how voters distinguished among the progressive parties.

Taken together, the results in figure 2 illustrate that we have much to learn about the structure of municipal political competition from cast vote records, even when individuallevel survey data are not available for further analysis. The figure reveals two emergent dimensions of electoral competition: a recognizably ideological left-right divide on the first dimension, and, on the second dimension, an intra-ideological divide between establishment and upstart parties of the right. These results take us some distance toward clarifying the sources and structure of electoral competition in Vancouver.

Fortunately, we need not stop here. Our CMES data allow us to probe these emergent dimensions in considerably greater depth. As we explained above, we measured CMES respondents' vote choices within the measurement model that also included each of the 176,450 anonyimzed ballots, allowing for a measure of CMES respondents' spatial positions on the same scale as, and fully informed by, the cast vote records. By folding these spatial locations back into the CMES data, we can explore the individual-level features that are associated with respondents' positions on the two dimensions, producing a considerably more detailed interpretation of the two dimensions than would be possible with CVR data alone.

Figure 3 summarizes this analysis. We began by standardizing each of the 96 variables in the nine "families" of factors described in the previous section, and then calculated the correlation between respondents' positions on each variable and their ideal points on each of the two dimensions. In figure 3, we report results for any variable whose correlation coefficient was statistically significant for either of the two dimensions. Positive correlations are in blue, and negative correlations are in red, with stronger correlations in a deeper shade of each colour. To ease interpretation, variables are organized by the "families" described earlier.

The results displayed in figure 3 have much to teach us. Notice, first, that the number 

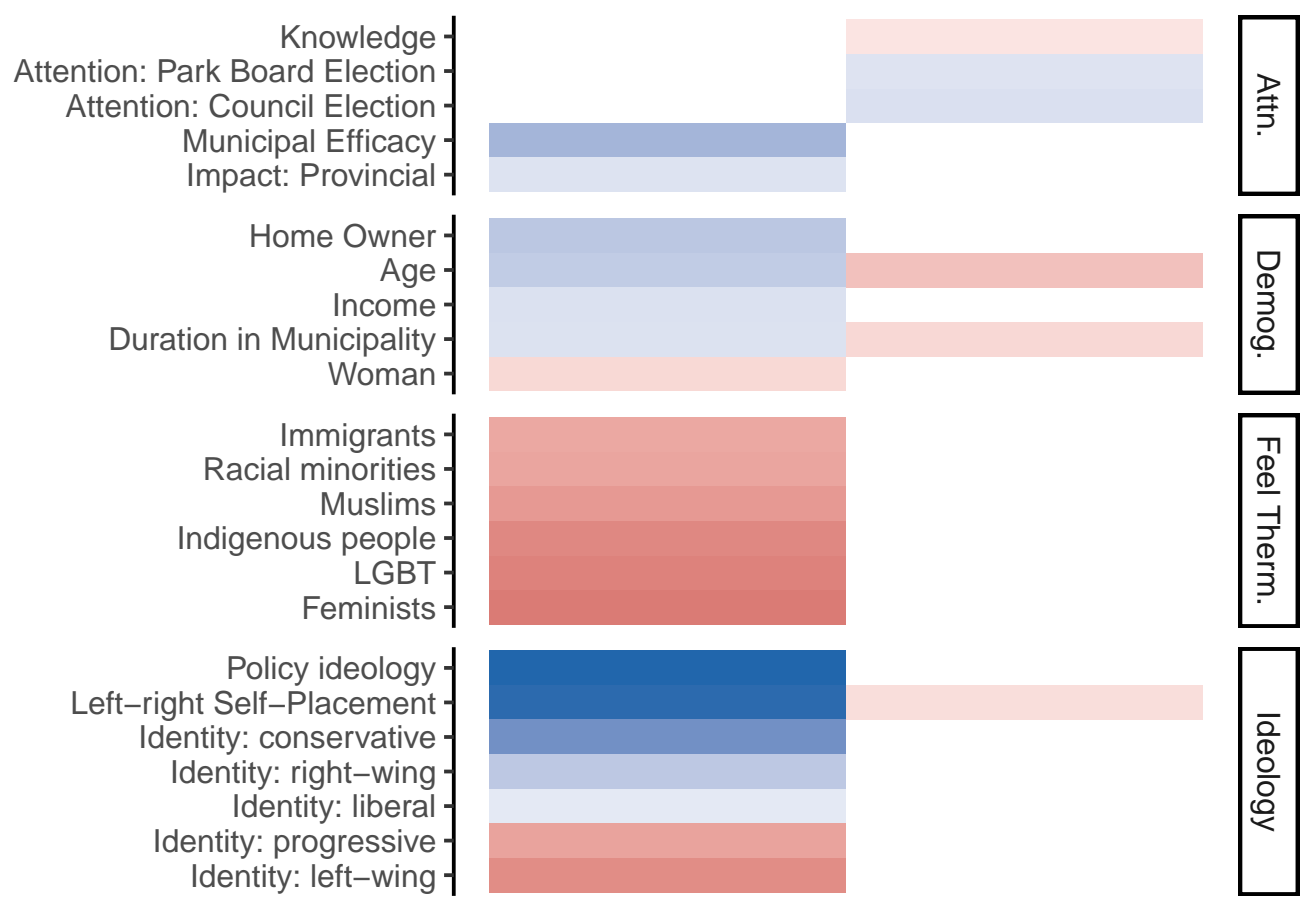

Issue position: reduce gap between rich/poor Issue position: government ensure equal standard Issue position: gender balance on council Issue position: racial balance on council Issue importance: property tax Issue position: government role in home values Issue importance: traffic and congestion Issue importance: economic development Issue position: immigrants help community Issue importance: transit Issue position: women's role Issue importance: homelessness Issue importance: affordability Issue position: government role in jobs Issue position: self to blame for failure -1
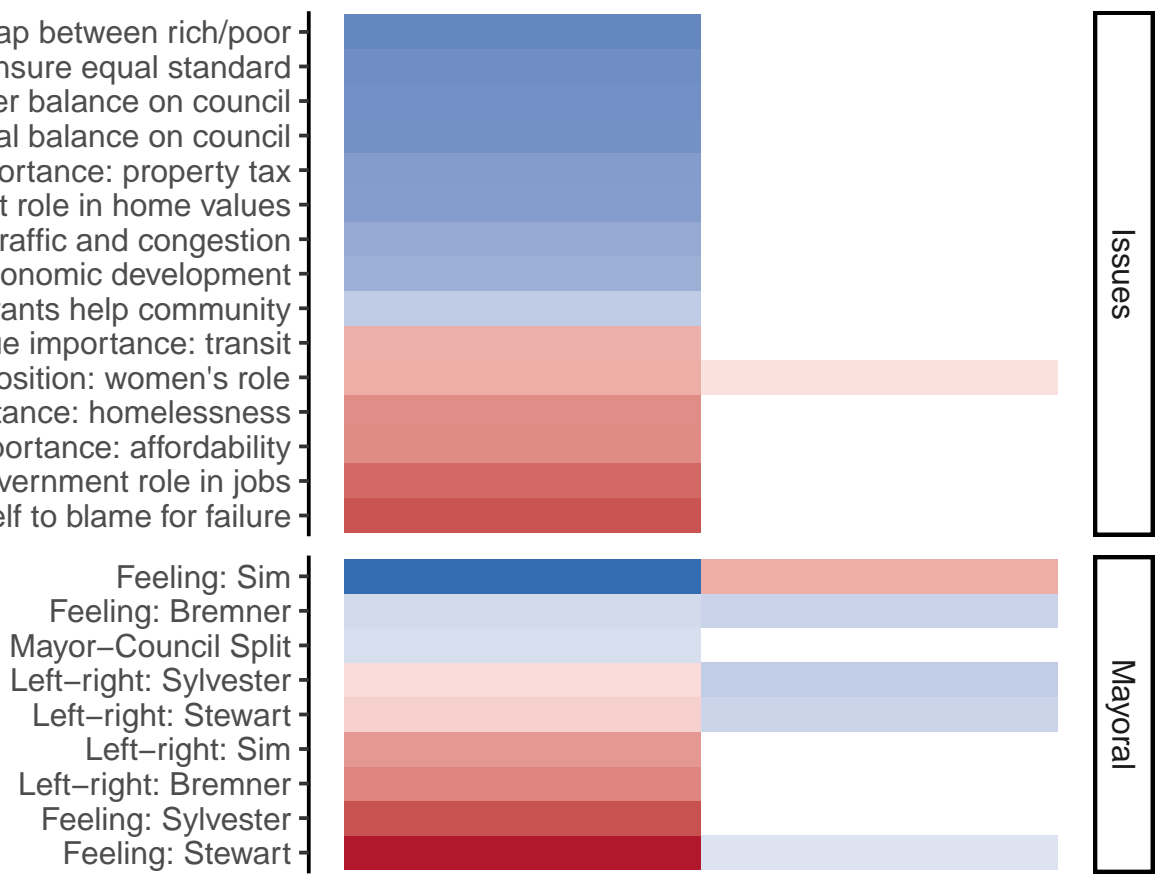

Prov. Partisanship: Liberal Fed. Partisanship: Conservative Fed. Partisanship: Green Prov. Partisanship: Green Fed. Partisanship: NDP Prov. Partisanship: NDP 1
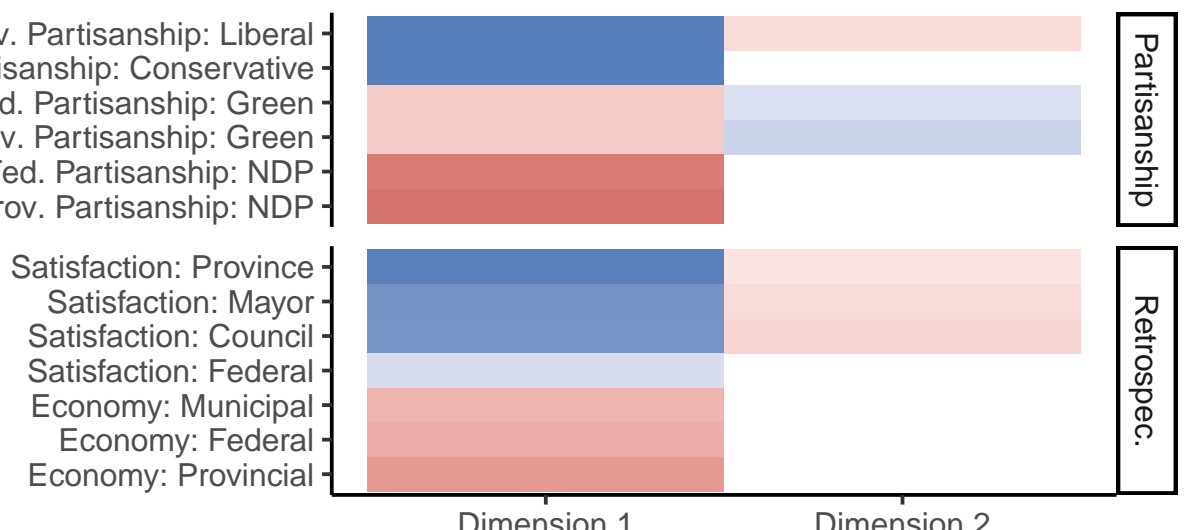

Dimension $1 \quad$ Dimension 2

$\begin{array}{lllll}-0.6 & -0.3 & 0.0 & 0.3 & 0.6\end{array}$

Figure 3: Correlations: CMES Vancouver Variables and Measured Dimensions 
of coloured variables is larger, and the shade of those variables is darker, for the first dimension than the second. This indicates that electoral competition in Vancouver is largely unidimensional; that is, many of the attitudinal and demographic variables that political scientists consider relevant to vote choice align strongly with the first dimension.

Inspecting the shaded variables for the first dimension more closely, we can see a number of distinct families of variables that are clearly important for interpreting respondents' spatial locations. In the ideology category, the two variables that capture respondents' ideological positions at the highest level of generality - their left-right self-placements and latent policy ideologies - are more strongly associated with the first dimension than any other variable in the figure. As expected, those who position themselves on the ideological right, and those whose latent policy attitudes are ideologically conservative, fall on the rightward end of our first-dimension measure. Relatedly, near the bottom of the figure, we can see that provincial and federal partisanship variables are also strongly associated with first-dimension positions. These relationships are equally intuitive: federal Conservatives and provincial Liberals on the right, Green and NDP partisans (both provincial and federal) on the left. Clearly, "left" and "right" on our measured spatial dimension align well with "left" and "right" in a more general ideological sense.

The strength and consistency of the associations in the "issues" family of variables is equally striking. All of the fourteen issue variables in the CMES study are associated with respondents' first-dimension positions, and all are related in the directions we would expect from more general ideological preferences. Importantly, issue questions related to specifically municipal policy debates are neither stronger nor weaker than more general questions. For example, a question about the government's role in home values (an extremely salient issue in the 2018 election) is no more strongly related to first-dimension scores than a more general question about the government's role in creating jobs. Issue relationships are strong across all policy questions, not just the municipal issues, which suggests that issue positions are connected to respondents' spatial locations by a more general policy ideology.

In addition to ideology, partisanship, and issue attitudes, several other variables are 
strongly associated with first-dimension scores. Feeling thermometer ratings for a variety of social groups are consistently related to first-dimension positions; in general, those on the rightward end of the first dimension have lower feeling thermometer scores when asked about historically marginalized groups than those on the left. Retrospection variables are also important, with those at the rightward end of the spectrum holding less optimistic economic views, and lower satisfaction ratings, than those on the left. These variables reflect the incumbent position of the Vision Vancouver council. Finally, several demographic variables are also associated with the first dimension, with older, male, wealthier, higher-income, longer-duration residents to the right, and their opposites to the left. These demographic relationships are also in keeping with what we would expect from an ideologically structured first dimension of municipal electoral competition.

Turning to the second dimension, notice first that fewer variables are significantly associated with respondents' ideal points on this dimension, and of those variables, relationships tend to be weaker (i.e. lighter shades) than on the first dimension. This is consistent with our interpretation of the second dimension as a genuinely secondary component of Vancouver's political structure, one that is primarily valuable for understanding intra-ideological divides on the right between NPA supporters (low scores on the second dimension) and the right-leaning upstart parties (higher values on the second dimension). In general, the correlation coefficients suggest that those with lower scores on the second dimension were were older, longer-duration Vancouver residents, placed themselves further to the right on the ideological spectrum, and held more traditional positions on women's role in society. Unsurprisingly, feelings toward Ken Sim (the NPA mayoral candidate) and Hector Bremner (the YES Vancouver candidate) are also strongly associated with positions on this dimension. More interesting are the statistically significant correlations for respondent's left-right placements of Stewart and Sylvester, the two leading progressive mayoral candidates; individuals who position those candidates further to the right had higher values on the second dimension, suggesting that NPA supporters believed Stewart and Sylvester to be more extreme "left-wingers" than did those who supported the newer right-leaning parties. In other words, among those who 
positioned themselves on the ideological right, supporters of the upstart parties felt less distant from the leading progressive mayoral candidates than did supporters of the NPA.

Of the correlations in the second-dimension results, just three variables are significantly associated with the second dimension but not the first: knowledge, council attention, and park board attention. Respondents' overall knowledge of Canadian politics (measured by a four-item battery of factual questions), together with their self-reported attentiveness to the city's council and park board elections, were not associated with their position on the main left-right axis of electoral competition. They were, however, associated with the second dimension, with more knowledgeable respondents closer to the NPA, and higher-attention respondents closer to the upstart parties. Past research in Canadian municipal politics has suggested that citizens may attend more closely to municipal politics when they are seeking out alternatives to incumbent candidates (Moore, McGregor, and Stephenson 2017), and the same may be true in relation to establishment versus upstart political parties. With the Non-Partisan Association comfortably occupying a role as the "default" party of the right for nearly a century, it is hardly surprising that those who were closer to the upstart parties on the second dimension were also more likely to report that they had paid close attention to the election.

Overall, then, our findings suggest that a second dimension is helpful for understanding municipal voting in Vancouver - but that the character of this second dimension looks rather different than what we would expect from the "urbanist versus conservationist" axis described prior to the election and from the "market role in land use" dimension that researchers have uncovered in some studies of American municipal policy attitudes (Cann 2018; Bucchianeri et al. 2019). We find no evidence in our results of an issue or cluster of issues - whether it be housing affordability, local land use policy, provincial or federal partisanship, or some other source of contention - that is genuinely cross-cutting for Vancouver voters. If this were the case, we would see more variation on the second dimension among left-leaning Vancouver voters and parties, and we would see stronger relationships in the CMES survey data between issue or partisan variables and respondents' positions in the second dimension of basic space. Instead, we find that the second 
dimension primarily reflects an intra-ideological controversy among Vancouver voters on the right: on the one hand, highly attentive, knowleddgeable, younger, and more moderate voters who are more willing to support an "upstart" right-leaning party, and on the other hand, older, less engaged voters who are happy to stick with the city's traditional conservative alternative, the Non-Partisan Association. Thus, despite the importance of the second dimension that we have recovered, we interpret the latent structure of Vancouver's 2018 voting results as primarily one-dimensional in character - a dimension that can safely be described as "ideological" in character.

\section{Discussion}

Our approach in this paper has been to use novel cast vote records to measure the locations of Vancouver's 2018 voters and candidates in a shared two-dimensional political space, and then interpret that structure using nearly 100 individual-level survey variables from the Canadian Municipal Election Study. We have sought to develop a measurement strategy that allows us to grapple with an exceptionally complex electoral system, one in which Vancouver voters have the opportunity to select a mayoral candidate, ten councillors, seven park board commissioners, and nine school board trustees at each election. To properly interpret the structure of political competition in big cities, it is important to move beyond mayoral elections and assess what local residents' full array of choices tells us about the local political environment (Warshaw 2019). Our approach has provided us with a means with which to do just that.

What have we learned from this new approach? First, our findings suggest that municipal electoral competition in Vancouver is structured primarily by a single dimension of competition - one that is strongly related to general patterns of ideology, partisanship, and issue positions. While Vancouver's party system is unique, the political space in which those parties compete for votes is not. Those on the "left" of this first dimension in Vancouver municipal politics are recognizable as ideologically "left" in provincial or federal politics: they adopt left-of-centre ideological self-placements, hold recognizably 
progressive issue positions, and identify more closely with provincial and federal parties of the left. The same is true, in mirror image, of those on the right. While Vancouver's municipal elections are certainly not "nationalized" in the sense that elections are dominated by national policy issues or party affiliations, left-right divides that are familiar from politics at other levels - including voters' party identities and ideological self-understandings - are strongly related to their voting decisions at the municipal level as well.

To the extent that a second dimension of competition is active in Vancouver municipal politics, our analysis suggests that it primarily divides those on the ideological right into supporters of the well-established NPA versus those who support newer centre-right parties. At first glance, we might suspect that this intra-ideological divide on the right is connected to a more general phenomenon, observed in many advanced democracies, of a united "left" and a more ideologically fragmented "right" (Cochrane 2013); however, it is important to recognize that Vancouver residents' issue positions, and even their more general ideological self-placements, are only very weakly related to their seconddimension locations. Instead, the divide appears to be more generational in character: older, long-time Vancouver residents who are dissatisfied with council's performance are more likely NPA supporters, and younger residents who are ideologically conservative but feel less distant from the city's progressive candidates and council are more tempted by the newer parties. The small overall size of this second demographic group - young, highly attentive, ideologically conservative residents - in the progressive city of Vancouver may help account for the upstart parties' notable lack of success in 2018.

More generally, our analysis suggests that the ideological and issue disagreements that animate Canadian politics at the provincial levels are fully active in Vancouver's municipal politics as well; however, these divides take on a distinctive complexion at the municipal level as a result of Vancouver's electoral institutions and generally left-leaning public. Atlarge elections, linked with a majoritarian electoral formula, create low barriers to entry for new political parties, and when those parties are willing to coordinate, even only partially, multiple parties occupying a similar ideological space can each run candidates 
while still avoiding sub-optimal outcomes from vote-splitting. What is most distinctive about Vancouver's politics, in other words, appears to have less to do with the fact that the elections are municipal - that the elected representatives will be responsible for a very particular array of policy tasks - and more to do with the ideological composition of the city's electorate and the strategic incentives created by its distinctive institutions.

\section{Conclusion}

Our analysis in this paper suggests several new lines of research for urban political scientists. One interesting puzzle relates to Vancouver's centre-left parties: why do we see four progressive parties in Vancouver, given that the parties are positioned at very similar points in our measured political space? One answer is historical; Vision Vancouver emerged as a moderate alternative to the "hard left" COPE, creating new party loyalties and "brands" even as many progressive voters are now happy to support candidates from both parties. Much the same is true of OneCity, whose birth owed as much to intraparty tensions within COPE as to deep ideological disagreement. A second important line of explanation may be the sheer abundance of progressive voters in Vancouver; in a city whose residents are mostly left of centre in the larger Canadian context, parties can cater especially to particular varieties of the larger progressive whole: Green as the home for environmentally-conscious moderates; COPE as the home for progressives outraged by the city's stark economic inequalities; OneCity as COPE with a friendlier, younger, and more "new left" appeal. Provided that these parties are able to coordinate to some degree in the candidates they field for Vancouver's at-large offices, all can persist, and enjoy some success, without threatening the overall strength of progressive representation on city council. Whatever the precise cause, our analysis illuminates the puzzle - four parties, all closely related on the primary dimension of competition and indistinguishable on the secondary dimension - and the need for additional research on party strategy, candidate entry, and vote choice on the progressive side of Vancouver's ideological spectrum (DeLeon 1992). 
We also see considerable value in additional research on right-of-centre parties in Vancouver and similar cities. Since 2018, tensions within the Non-Partisan Association have only increased; the NPA recently announced that John Coupar, a longtime party member and park board commissioner who unsuccessfully sought the NPA's mayoral nomination in 2018, would be the party's mayoral candidate in 2022, provoking surprise, and then outrage, among many party members. Councillors Lisa Dominato, Colleen Hardwick, and Sarah Kirby-Yung soon resigned from the NPA and now sit as independents; their party affiliation in the 2022 election, should they choose to run, remains unclear. Ken Sim, NPA's narrowly defeated 2018 mayoral candidate, has launched a new party and also intends to run for mayor in 2022. Perhaps, like The Electors Action Movement in the 1970s, one of these emerging alternatives will come to serve as a genuine challenge to the more traditionalist NPA. Or they may evolve into competing parties of the right, embodying the alternative right-of-centre visions - automobile-friendly populism, pro-development market liberalism, anti-development conservationism - that have been visible in other Canadian cities (Magnusson 1983b; Silver, Taylor, and Calderón-Figueroa 2020) and in comparative politics research on right-of-centre policy platforms in multi-party electoral systems (Cochrane 2013). Whatever the outcome, our analysis serves as a basis for additional work on the sources of intra-ideological tensions on Vancouver's ideological right. Future research involving more specific questions about issues that may internally divide Vancouver's right-leaning voters (and, for that matter, voters on the left as well), would be a valuable next step for interpreting these tensions.

While our primary focus throughout this analysis has been to interpret the structure of municipal voting behaviour in Vancouver in particular, our findings also have implications for our more general understanding of contemporary local politics. Unlike other recent studies, we do not find evidence of a second dimension of conflict in Vancouver that is animated by cross-cutting policy issues related to land use or the role of the market in local politics (Cann 2018; Bucchianeri et al. 2021); indeed, we find that Vancouver's second dimension of competition created very little cross-cutting pressure for voters and candidates on the left. Thus, in the context of broader debates about the 
character of municipal electoral competition - the "no dimensions" thesis of unstructured or idiosyncratic local competition, the "one dimension" thesis of competition organized around recognizable left-right divides, and the "two dimension" thesis of left-right debates alongside orthogonal local policy issues that cross-cut the traditional left-right cleavage - Vancouver's 2018 principally supports the "one-dimensional" school of thought.

We also hope that our work illustrates the potential for cast vote records - anonymized records of every vote cast in an election - to provide new insight on the structure of political competition in municipal politics. Even when researchers do not have access to an election survey, cast vote records can be valuable for understanding patterns of singleticket and split-ticket voting and ballot roll-off, and for estimating the underlying sources of variation that account for voters' choices across a large number of local offices. These latent sources of variation can be interpreted with survey data, when available, but they could also be interpreted using interviews with local political observers or candidates, textual analysis using traditional media or social media data, or analysis of candidates' campaign activities and policy commitments. In short, the particular combination of cast vote records and survey data that we exploit in this paper, while valuable, is by no means the only possible approach to interpreting the structure of municipal voting patterns revealed by the anonymized voting data.

Opportunities for researchers to make use of these data will, we hope, expand substantially in the coming years. At the beginning of this research project, we searched the open data platforms of the fifty largest cities in Canada and contacted municipal clerks and election administrators to locate CVR data in other cities. At present, Vancouver is the only municipality in Canada to make these data publicly available. However, as increasing numbers of municipalities adopt electronic vote tabulators, the opportunity to access CVR data will increase, and in our experience, many municipal election administrators are not yet aware that researchers have an interest in these data. We encourage urban political scientists to advocate for publicly available CVR data in their cities. 


\section{$7 \quad$ References}

Agadjanian, Alexander, and Jonathan Robinson. 2019. "Ground Truth Validation of Survey Estimates of Split-Ticket Voting with Cast Vote Records Data."

Anderson, Cameron D., R. Michael McGregor, Aaron A. Moore, and Laura B. Stephenson. 2015. Economic Voting and Multilevel Governance. Vol. 53. 1. https: //doi.org/10.1177/1078087415617302.

Anzia, Sarah F. 2021. "Party and Ideology in American Local Government: An Appraisal." Annual Review of Political Science 24 (1): 1-18. https://doi.org/10. 1146/annurev-polisci-041719-102131.

Armstrong, David A. II, Ryan Bakker, Royce Carroll, Christopher Hare, Keith T. Poole, and Howard Rosenthal. 2021. Analyzing Spatial Models of Choice and Judgment. Boca Raton: CRC Press.

Bafumi, Joseph, Michael C. Herron, Seth J. Hill, and Jeffrey B. Lewis. 2012. "Alvin Greene? Who? How Did He Win the United States Senate Nomination in South Carolina?" Election Law Journal: Rules, Politics, and Policy 11 (4): 358-79. https: //doi.org/10.1089/elj.2011.0137.

Borwein, Sophie, and Jack Lucas. 2021. "Municipal Identity and City Interests." Political Behavior.

Boudreau, Cheryl, Christopher S. Elmendorf, and Scott A. MacKenzie. 2015. "Lost in Space? Information Shortcuts, Spatial Voting, and Local Government Representation." Political Research Quarterly 68 (4): 843-55. https://doi.org/10.1177/ 1065912915609437.

Bridges, Amy. 1999. Morning Glories: Municipal Reform in the Southwest. Princeton: Princeton University Press.

Bright, David. 1998. The Limits of Labour: Class Formation and the Labour Movement in Calgary, 1883-1929. Vancouver: UBC Press.

Bucchianeri, Peter. 2018. "There's More than One Way to Party: Progressive Politics and Representation in Nonpartisan San Francisco." Unpublished Manuscript. http: //bit.1y/2VnDCBA. 
Bucchianeri, Peter, Riley Carney, Ryan Enos, Amy Lakeman, and Gabrielle Malina. 2021. "What explains local policy cleavages? Examining the policy preferences of public officials at the municipal level." Social Science Quarterly, 1-9. https://doi. org/10.1111/ssqu.13039.

Bucchianeri, Peter, Riley Carney, Ryan Enos, and Gabrielle Malina. 2019. "What Explains Local Policy Cleavages ? Examining the Policy Preferences of Public O cials at the Municipal Level."

Bula, Frances. 2018. "My intersectional, diverse, covering-all-bases voters' guide to Vancouver council." State of Vancouver 10 (19): 1.

Burnett, Craig M. 2019. "Parties as an organizational force on nonpartisan city councils." Party Politics 25 (4): 594-608. https://doi.org/10.1177/1354068817737996.

Bushfield, Ian, and Stewart Prest. 2018. Plotting the Vancouver Political Parties. Vancouver: Cambie Report.

Cann, Damon M. 2018. "The Structure of Municipal Political Ideology." State and Local Government Review 50 (1): 37-45. https://doi.org/10.1177/0160323x18781456.

Caughey, Devin, T. O. M. O’Grady, and Christopher Warshaw. 2019. "Policy ideology in European Mass Publics, 1981-2016." American Political Science Review 113 (3): 674-93. https://doi.org/10.1017/S0003055419000157.

Cochrane, Christopher. 2013. "The asymmetrical structure of left/right disagreement: Left-wing coherence and right-wing fragmentation in comparative party policy." Party Politics 19 (1): 104-21. https://doi.org/10.1177/1354068811398057.

Cutler, Fred, and J Scott Matthews. 2005a. "The challenge of municipal voting: Vancouver 2002." Canadian Journal of Political Science 38 (2): 359-82. https://doi. $\operatorname{org} / 10.1017 / \mathrm{s} 0008423905040151$

—. 2005b. "The Challenge of Municipal Voting: Vancouver 2002." Canadian Journal of Political Science 38 (2): 359-82.

DeLeon, Richard Edward. 1992. Left Coast City: Progressive Politics in San Francisco, 1975-1991. Lawrence: University of Kansas Press.

Epp-Koop, Stefan. 2015. We're Going to Run this City: Winnipeg's Political Left After 
the General Strike. Winnipeg: University of Manitoba Press.

Fischel, William A. 2005. The Homevoter Hypothesis. Cambridge: Harvard University Press.

Gerber, Elisabeth R, and Ken Kollman. 2004. "Introduction - Authority Migration: Defining an Emerging Research Agenda." Political Science and Politics 37 (3): 397401.

Gimpel, James G., Nathan Lovin, Bryant Moy, and Andrew Reeves. 2019. "The UrbanRural Gulf in American Political Behavior." Political Behavior Forthcomin.

Godbout, Jean-François. 2020. Lost on Division: Party Unity in the Canadian Parliament. Toronto: University of Toronto Press.

Gutstein, Donald. 1983. "Vancouver." In City Politics in Canada, edited by Warren Magnusson and Andrew Sancton, 189-221. Toronto: University of Toronto Press.

Hajnal, Zoltan, and Jessica Trounstine. 2014. "What Underlies Urban Politics? Race, Class, Ideology, Partisanship, and the Urban Vote." Urban Affairs Review 50 (1): 63-99. https://doi.org/10.1177/1078087413485216.

Herron, Michael C., and Jeffrey B. Lewis. 2007. "Did Ralph Nader Spoil Al Gore's Presidential Bid? A Ballot-Level Study of Green and Reform Party Voters in the 2000 Presidential Election." Quarterly Journal of Political Science 2 (3): 205-26. https://doi.org/10.1561/100.00005039.

Holman, Mirya R., and J. Celeste Lay. 2020. "Are You Picking Up What I Am Laying Down? Ideology in Low-Information Elections." Urban Affairs Review, 1-27. https: //doi.org/10.1177/1078087420908933.

—. 2021. "Are You Picking Up What I Am Laying Down? Ideology in LowInformation Elections." Urban Affairs Review 57 (2): 315-41. https://doi.org/ $10.1177 / 1078087420908933$.

Hopkins, Daniel J. 2018. The Increasingly United States. Chicago: University of Chicago Press.

Hopkins, Daniel J., and Lindsay M. Pettingill. 2018. "Retrospective Voting in BigCity US Mayoral Elections." Political Science Research and Methods 6 (4): 697-714. 
https://doi.org/10.1017/psrm.2016.54.

Jessee, Stephen. 2012. Ideology and Spatial Voting in American Elections. Cambridge: Cambridge University Press.

Kal Munis, B. 2021. "Place, candidate roots, and voter preferences in an age of partisan polarization: Observational and experimental evidence." Political Geography 85

(October 2020): 102345. https://doi.org/10.1016/j.polgeo.2021.102345.

Kaufmann, Karen M. 2004. The Urban Voter. Ann Arbor: University of Michigan Press. Kucukelbir, Alp, Dustin Tran, Rajesh Ranganath, Andrew Gelman, and David M. Blei. 2017. "Automatic Differentiation Variational Inference." Journal of Machine Learning Research 18: 1-45. http://arxiv.org/abs/2003.01687.

Kuriwaki, Shiro. 2019. "Party Loyalty on the Long Ballot: Is Ticket Splitting More Prevalent in State and Local Elections?" https://doi.org/10.31235/osf .io/bvgz3. Lucas, Jack. 2020. "Reaction or Reform? Subnational Evidence on PR Adoption from Canadian Cities." Representation 56 (1): 89-109. 2021. "The Size and Sources of Municipal Incumbency Advantage in Canada."

Urban Affairs Review 57 (2): 373-401. https://doi.org/https://doi.org/10.5683/ SP2/8BLD2I.

- 2022. "Do 'Non-Partisan' Politicians Match the Partisanship of their Constituents?" Urban Affairs Review 58 (1): 103-28.

Lucas, Jack, and David A. Armstrong II. 2021. "Policy Ideology and Local Ideological Representation in Canada." Canadian Journal of Political Science 54 (4): 959-76.

Lucas, Jack, and R. Michael McGregor. 2020. "Conclusion." In Big City Elections in Canada. Toronto: University of Toronto Press.

Lucas, Jack, and John Santos. 2021. "Calgary." In Big City Elections in Canada, edited by Jack Lucas and R. Michael McGregor. Toronto: University of Toronto Press.

Madden, Wayne D. 2003. Vancouver's Elected Representatives. Vancouver: Wayne D. Madden.

Magnusson, Warren. 1983a. "Introduction." In City Politics in Canada, edited by Warren Magnusson and Andrew Sancton, 3-57. Toronto: University of Toronto Press. 
1983b. "Toronto." In City Politics in Canada, edited by Warren Magnusson and Andrew Sancton, 94-139. Toronto: University of Toronto Press.

Martin, Osvaldo. 2018. Bayesian Analysis with Python. Birmingham: Packt Publishing. Mcgregor, Michael, and Zachary Spicer. 2016. "The Canadian homevoter: Property values and municipal politics in Canada." Journal of Urban Affairs 38 (1): 123-39. https://doi.org/10.1111/juaf.12178.

McGregor, R. Michael, Cameron D. Anderson, Éric Bélanger, Sandra Breux, Jack Lucas, J. Scott Matthews, Anne Mévellec, et al. 2021. "The Canadian Municipal Election Study." Frontiers in Political Science 3 (September): 1-6. https://doi.org/10. 3389/fpos. 2021.745331.

Moore, Aaron A, R Michael McGregor, and Laura B Stephenson. 2017. "Paying attention and the incumbency effect: Voting behavior in the 2014 Toronto Municipal Election." International Political Science Review 38 (1): 85-98. https://doi.org/10.1177/ 0192512115616268.

Oliver, J. Eric. 2012. Local Elections and the Politics of Small-Scale Democracy. Chicago: University of Chicago Press.

Oliver, J. Eric, and S E Ha. 2007. "Vote choice in suburban elections." American Political Science Review 101 (3): 393-408. https://doi.org/10.1017/S0003055407070323.

Pike, Allen. 2018. Vancouver Election Guide 2018. Vancouver: Allen Pike. https: //allenpike.com/2018/vancouver-election-guide.

Poole, Keith T., and Howard Rosenthal. 1997. Congress: A Political-Economic History of Roll Call Voting. Oxford: Oxford University Press.

Rooij, Elaine de, J Scott Matthews, and Mark Pickup. 2020. "Vancouver." In Big City Elections in Canada, edited by Jack Lucas and R. Michael McGregor. Toronto: University of Toronto Press.

Salvatier, John, Thomas V. Wiecki, and Christopher Fonnesbeck. 2016. "Probabilistic programming in Python using PyMC3." PeerJ Computer Science 2016 (4): 1-24. https://doi.org/10.7717/peerj-cs.55.

Sances, Michael W. 2018. "Ideology and Vote Choice in U.S. Mayoral Elections: Evidence 
from Facebook Surveys." Political Behavior 40 (3): 737-62. https://doi.org/10. 1007/s11109-017-9420-x.

Schaffner, Brian F., Jesse H. Rhodes, and Raymond J. La Raja. 2020. Hometown Inequality: Race, Class, and Representation in American Local Politics. Cambridge: Cambridge University Press.

Silver, Daniel, Zack Taylor, and Fernando Calderón-Figueroa. 2020. "Populism in the City: the Case of Ford Nation." International Journal of Politics, Culture and Society 33 (1): 1-21. https://doi.org/10.1007/s10767-018-9310-1.

Stephenson, Laura B., R. Michael McGregor, and Aaron A. Moore. 2018. "Sins of the Brother: Partisanship and Accountability in Toronto, 2014." In Accountability and Responsiveness at the Municipal Level: Views from Canada, edited by Sandra Breux and Jérôme Couture, 23-48. Montreal; Kingston: McGill-Queen's University Press.

Tausanovitch, Chris, and Christopher Warshaw. 2013. "Measuring constituent policy preferences in congress, state legislatures, and cities." Journal of Politics 75 (2): 330-42. https://doi.org/10.1017/S0022381613000042.

2014. "Representation in Municipal Government." American Political Science Review 108 (03): 605-41. https://doi.org/10.1017/S0003055414000318.

Taylor, Zack. 2019. Shaping the Metropolis. Montreal; Kingston: McGill-Queen's University Press.

Tennant, Paul. 1980. "Vancouver civic politics, 1929-1980." BC Studies: The British Columbian Quarterly, no. 46: 3-27. http://prophet.library.ubc.ca/ojs/index. php/bcstudies/article/download/1054/1092.

Trounstine, Jessica. 2008. Political Monopolies in American Cities. Chicago: University of Chicago Press.

Vogel, Donna. 2003. Challenging Politics. Vancouver: Fernwood Publishing.

Warshaw, Christopher. 2019. "Local Elections and Representation in the United States." Annual Review of Political Science 22 (1): 1-19. https://doi.org/10.1146/annurevpolisci-050317-071108.

Wong, Cara J. 2010. Boundaries of Obligation in American Politics. Cambridge: Cam- 
bridge University Press. 


\section{Appendix: Survey Questions}

\begin{tabular}{|c|c|c|}
\hline Variable & Category & Question Wording \\
\hline Knowledge 4 & Attention / Interest & $\begin{array}{l}\text { Do you happen to know how many city councillors } \\
\text { Vancouver has? (response options: actual answer } \\
6,8,10,12 \text {,don't know) }\end{array}$ \\
\hline Knowledge 3 & Attention / Interest & $\begin{array}{l}\text { Do you happen to know the name of the Finance } \\
\text { Minister of Canada? (response options: Joe Oliver, Jim } \\
\text { Flaherty, Paul Martin, Bill Morneau, don't know) }\end{array}$ \\
\hline Knowledge 1 & Attention / Interest & $\begin{array}{l}\text { Do you happen to know the name of the Premier of } \\
\text { British Columbia (response options: name of deputy } \\
\text { premier, name of previous premier, correct response, } \\
\text { name of leader of opposition, don't know) }\end{array}$ \\
\hline Knowledge 2 & Attention / Interest & $\begin{array}{l}\text { Do you happen to remember the name of the Mayor if } \\
\text { Vancouver prior to Gregor Robertson? (response } \\
\text { options: correct answer, name of mayor prior to last, } \\
\text { name of deputy mayor, name of the mayor of a nearby } \\
\text { large city, don't know) }\end{array}$ \\
\hline Impact: Municipal & Attention / Interest & $\begin{array}{l}\text { Governments at all levels make decisions that have the } \\
\text { potential to impact the lives of citizens. Please indicate } \\
\text { how much impact each level of government has upon } \\
\text { your quality of life. }\end{array}$ \\
\hline Impact: Provincial & Attention / Interest & $\begin{array}{l}\text { Governments at all levels make decisions that have the } \\
\text { potential to impact the lives of citizens. Please indicate } \\
\text { how much impact each level of government has upon } \\
\text { your quality of life. }\end{array}$ \\
\hline Impact: Federal & Attention / Interest & $\begin{array}{l}\text { Governments at all levels make decisions that have the } \\
\text { potential to impact the lives of citizens. Please indicate } \\
\text { how much impact each level of government has upon } \\
\text { your quality of life. }\end{array}$ \\
\hline Interest: Federal politics & Attention / Interest & How interested are you in federal politics? \\
\hline Interest: Municipal politics & Attention / Interest & How interested are you in municipal politics? \\
\hline Interest: Park Board politics & Attention / Interest & How interested are you in park board politics? \\
\hline Interest: Provincial politics & Attention / Interest & How interested are you in provincial politics? \\
\hline Federal Efficacy & Attention / Interest & $\begin{array}{l}\text { How much do you think the following care about what } \\
\text { people like you think: a lot, some, a little or none? } \\
\text { Federal Government }\end{array}$ \\
\hline Municipal Efficacy & Attention / Interest & $\begin{array}{l}\text { How much do you think the following care about what } \\
\text { people like you think: a lot, some, a little or none? } \\
\text { Municipal Government }\end{array}$ \\
\hline
\end{tabular}




\begin{tabular}{|c|c|c|}
\hline Variable & Category & Question Wording \\
\hline Provincial Efficacy & Attention / Interest & $\begin{array}{l}\text { How much do you think the following care about what } \\
\text { people like you think: a lot, some, a little or none? } \\
\text { Provincial Government }\end{array}$ \\
\hline General Efficacy & Attention / Interest & Index of three efficacy questions \\
\hline Attention: Council Election & Attention / Interest & $\begin{array}{l}\text { On a scale of } 0-10, \text { how much attention did you pay } \\
\text { to... the council election? }\end{array}$ \\
\hline Attention: Mayoral Election & Attention / Interest & $\begin{array}{l}\text { On a scale of } 0-10, \text { how much attention did you pay } \\
\text { to. . the mayoral election campaign? }\end{array}$ \\
\hline Attention: Park Board Election & Attention / Interest & $\begin{array}{l}\text { On a scale of } 0-10, \text { how much attention did you pay } \\
\text { to... the park board election? }\end{array}$ \\
\hline $\begin{array}{l}\text { Neighbourhood Association } \\
\text { Member }\end{array}$ & Community & $\begin{array}{l}\text { In the last } 12 \text { months, have you been a member of, or } \\
\text { volunteered with: A community association? }\end{array}$ \\
\hline Identity: Province & Community & $\begin{array}{l}\text { Please indicate how closely you identify with each of the } \\
\text { following: British Columbia }\end{array}$ \\
\hline Identity: Country & Community & $\begin{array}{l}\text { Please indicate how closely you identify with each of the } \\
\text { following: Canada }\end{array}$ \\
\hline Identity: Neighbourhood & Community & $\begin{array}{l}\text { Please indicate how closely you identify with each of the } \\
\text { following: Vancouver }\end{array}$ \\
\hline Identity: City & Community & $\begin{array}{l}\text { Please indicate how closely you identify with each of the } \\
\text { following: Your neighbourhood }\end{array}$ \\
\hline Pride: City & Community & $\begin{array}{l}\text { Please indicate how much pride you have in each of the } \\
\text { following: Vancouver }\end{array}$ \\
\hline Pride: Neighbourhood & Community & $\begin{array}{l}\text { Please indicate how much pride you have in each of the } \\
\text { following: your neighbourhood }\end{array}$ \\
\hline Pride: Province & Community & $\begin{array}{l}\text { Please indicate how much pride you have in each of the } \\
\text { following: British Columbia }\end{array}$ \\
\hline Pride: Country & Community & $\begin{array}{l}\text { Please indicate how much pride you have in each of the } \\
\text { following: Canada }\end{array}$ \\
\hline Racial minorities & Feeling Thermometers & $\begin{array}{l}\text { How do you feel about each of the following groups? } \\
\text { Please use the sliders to indicate your feelings on a scale } \\
\text { from } 0 \text { to } 100 \text {, where zero means you REALLY DISLIKE } \\
\text { the group and one hundred means you REALLY LIKE } \\
\text { the group. }\end{array}$ \\
\hline Immigrants & Feeling Thermometers & $\begin{array}{l}\text { How do you feel about each of the following groups? } \\
\text { Please use the sliders to indicate your feelings on a scale } \\
\text { from } 0 \text { to } 100, \text { where zero means you REALLY DISLIKE } \\
\text { the group and one hundred means you REALLY LIKE } \\
\text { the group. }\end{array}$ \\
\hline
\end{tabular}




\begin{tabular}{|c|c|c|}
\hline Variable & Category & Question Wording \\
\hline LGBT & Feeling Thermometers & $\begin{array}{l}\text { How do you feel about each of the following groups? } \\
\text { Please use the sliders to indicate your feelings on a scale } \\
\text { from } 0 \text { to } 100, \text { where zero means you REALLY DISLIKE } \\
\text { the group and one hundred means you REALLY LIKE } \\
\text { the group. }\end{array}$ \\
\hline Feminists & Feeling Thermometers & $\begin{array}{l}\text { How do you feel about each of the following groups? } \\
\text { Please use the sliders to indicate your feelings on a scale } \\
\text { from } 0 \text { to } 100, \text { where zero means you REALLY DISLIKE } \\
\text { the group and one hundred means you REALLY LIKE } \\
\text { the group. }\end{array}$ \\
\hline Muslims & Feeling Thermometers & $\begin{array}{l}\text { How do you feel about each of the following groups? } \\
\text { Please use the sliders to indicate your feelings on a scale } \\
\text { from } 0 \text { to } 100, \text { where zero means you REALLY DISLIKE } \\
\text { the group and one hundred means you REALLY LIKE } \\
\text { the group. }\end{array}$ \\
\hline Caucasians & Feeling Thermometers & $\begin{array}{l}\text { How do you feel about each of the following groups? } \\
\text { Please use the sliders to indicate your feelings on a scale } \\
\text { from } 0 \text { to } 100 \text {, where zero means you REALLY DISLIKE } \\
\text { the group and one hundred means you REALLY LIKE } \\
\text { the group. }\end{array}$ \\
\hline Indigenous people & Feeling Thermometers & $\begin{array}{l}\text { How do you feel about each of the following groups? } \\
\text { Please use the sliders to indicate your feelings on a scale } \\
\text { from } 0 \text { to } 100, \text { where zero means you REALLY DISLIKE } \\
\text { the group and one hundred means you REALLY LIKE } \\
\text { the group. }\end{array}$ \\
\hline Left-right Self-Placement & Ideology & $\begin{array}{l}\text { In politics people sometimes talk of left and right. } \\
\text { Where would you place yourself on a scale from } 0 \text { to } 10 \text {, } \\
\text { where } 0 \text { means left and } 10 \text { means right? }\end{array}$ \\
\hline Identity: conservative & Ideology & $\begin{array}{l}\text { When it comes to municipal politics, do you think of } \\
\text { yourself as a..conservative? }\end{array}$ \\
\hline Identity: left-wing & Ideology & $\begin{array}{l}\text { When it comes to municipal politics, do you think of } \\
\text { yourself as a..left-wing? }\end{array}$ \\
\hline Identity: liberal & Ideology & $\begin{array}{l}\text { When it comes to municipal politics, do you think of } \\
\text { yourself as a..liberal? }\end{array}$ \\
\hline Identity: libertarian & Ideology & $\begin{array}{l}\text { When it comes to municipal politics, do you think of } \\
\text { yourself as a..libertarian? }\end{array}$ \\
\hline Identity: progressive & Ideology & $\begin{array}{l}\text { When it comes to municipal politics, do you think of } \\
\text { yourself as a..progressive? }\end{array}$ \\
\hline
\end{tabular}




\begin{tabular}{|c|c|c|}
\hline Variable & Category & Question Wording \\
\hline Identity: right-wing & Ideology & $\begin{array}{l}\text { When it comes to municipal politics, do you think of } \\
\text { yourself as a..right-wing? }\end{array}$ \\
\hline $\begin{array}{l}\text { Issue position: government role in } \\
\text { jobs }\end{array}$ & Issues & $\begin{array}{l}\text { Government should leave it entirely up to the private } \\
\text { sector to create jobs. }\end{array}$ \\
\hline $\begin{array}{l}\text { Issue position: government ensure } \\
\text { equal standard }\end{array}$ & Issues & $\begin{array}{l}\text { Government should see to it that everyone has a decent } \\
\text { standard of living. }\end{array}$ \\
\hline Issue position: government role in & Issues & Government should see to it that the cost of home \\
\hline home values & & ownership does not increase too quickly or too much. \\
\hline Issue importance: affordability & Issues & $\begin{array}{l}\text { How important are each of the following issues to you in } \\
\text { this election? Affordability }\end{array}$ \\
\hline $\begin{array}{l}\text { Issue importance: economic } \\
\text { development }\end{array}$ & Issues & $\begin{array}{l}\text { How important are each of the following issues to you in } \\
\text { this election? Economic development }\end{array}$ \\
\hline Issue importance: homelessness & Issues & $\begin{array}{l}\text { How important are each of the following issues to you in } \\
\text { this election? Homelessness }\end{array}$ \\
\hline Issue importance: property tax & Issues & $\begin{array}{l}\text { How important are each of the following issues to you in } \\
\text { this election? Property taxes }\end{array}$ \\
\hline Issue importance: transit & Issues & $\begin{array}{l}\text { How important are each of the following issues to you in } \\
\text { this election? Public transit }\end{array}$ \\
\hline $\begin{array}{l}\text { Issue importance: traffic and } \\
\text { congestion }\end{array}$ & Issues & $\begin{array}{l}\text { How important are each of the following issues to you in } \\
\text { this election? Traffic and congestion }\end{array}$ \\
\hline $\begin{array}{l}\text { Issue position: immigrants help } \\
\text { community }\end{array}$ & Issues & Immigrants make a positive contribution to Vancouver. \\
\hline $\begin{array}{l}\text { Issue position: reduce gap } \\
\text { between rich/poor }\end{array}$ & Issues & $\begin{array}{l}\text { More should be done to reduce the gap between the rich } \\
\text { and poor in Canada. }\end{array}$ \\
\hline $\begin{array}{l}\text { Issue position: self to blame for } \\
\text { failure }\end{array}$ & Issues & $\begin{array}{l}\text { People who don't get ahead should blame themselves, } \\
\text { not the system. }\end{array}$ \\
\hline Issue position: women's role & Issues & $\begin{array}{l}\text { Society would be better off if more women stayed home } \\
\text { with their children. }\end{array}$ \\
\hline $\begin{array}{l}\text { Issue position: gender balance on } \\
\text { council }\end{array}$ & Issues & $\begin{array}{l}\text { The gender composition of City Council should reflect } \\
\text { the gender composition of the population. (i.e. roughly } \\
50 \% \text { of the population is female, so } 50 \% \text { of councillors } \\
\text { should also be female). }\end{array}$ \\
\hline $\begin{array}{l}\text { Issue position: racial balance on } \\
\text { council }\end{array}$ & Issues & $\begin{array}{l}\text { The racial composition of City Council should reflect the } \\
\text { racial composition of the population. }\end{array}$ \\
\hline
\end{tabular}




\begin{tabular}{|c|c|c|}
\hline Variable & Category & Question Wording \\
\hline Feeling: Bremner & Mayoral & $\begin{array}{l}\text { How do you feel about each of the following mayoral } \\
\text { candidates? Please use the sliders to indicate your } \\
\text { feelings on a scale from } 0 \text { to } 100 \text {, where zero means you } \\
\text { REALLY DISLIKE the candidate and one hundred } \\
\text { means you REALLY LIKE the candidate. }\end{array}$ \\
\hline Feeling: Sim & Mayoral & $\begin{array}{l}\text { How do you feel about each of the following mayoral } \\
\text { candidates? Please use the sliders to indicate your } \\
\text { feelings on a scale from } 0 \text { to } 100 \text {, where zero means you } \\
\text { REALLY DISLIKE the candidate and one hundred } \\
\text { means you REALLY LIKE the candidate. }\end{array}$ \\
\hline Feeling: Stewart & Mayoral & $\begin{array}{l}\text { How do you feel about each of the following mayoral } \\
\text { candidates? Please use the sliders to indicate your } \\
\text { feelings on a scale from } 0 \text { to } 100 \text {, where zero means you } \\
\text { REALLY DISLIKE the candidate and one hundred } \\
\text { means you REALLY LIKE the candidate. }\end{array}$ \\
\hline Feeling: Sylvester & Mayoral & $\begin{array}{l}\text { How do you feel about each of the following mayoral } \\
\text { candidates? Please use the sliders to indicate your } \\
\text { feelings on a scale from } 0 \text { to } 100, \text { where zero means you } \\
\text { REALLY DISLIKE the candidate and one hundred } \\
\text { means you REALLY LIKE the candidate. }\end{array}$ \\
\hline Left-right: Bremner & Mayoral & $\begin{array}{l}\text { Using the same scale, where would you place the } \\
\text { following mayoral candidates? }\end{array}$ \\
\hline Left-right: Sim & Mayoral & $\begin{array}{l}\text { Using the same scale, where would you place the } \\
\text { following mayoral candidates? }\end{array}$ \\
\hline Left-right: Stewart & Mayoral & $\begin{array}{l}\text { Using the same scale, where would you place the } \\
\text { following mayoral candidates? }\end{array}$ \\
\hline Left-right: Sylvester & Mayoral & $\begin{array}{l}\text { Using the same scale, where would you place the } \\
\text { following mayoral candidates? }\end{array}$ \\
\hline Fed. Partisanship: Conservative & Partisanship & $\begin{array}{l}\text { In FEDERAL politics, do you usually think of yourself } \\
\text { as a: Liberal, Conservative, NDP, Green, Bloc, Other, } \\
\text { None of the Above, Don't know. (Selected Conservative } \\
\text { with "very" or "fairly" strong identity) }\end{array}$ \\
\hline Fed. Partisanship: Green & Partisanship & $\begin{array}{l}\text { In FEDERAL politics, do you usually think of yourself } \\
\text { as a: Liberal, Conservative, NDP, Green, Bloc, Other, } \\
\text { None of the Above, Don't know. (Selected Green with } \\
\text { "very" or "fairly" strong identity) }\end{array}$ \\
\hline
\end{tabular}




\begin{tabular}{|c|c|c|}
\hline Variable & Category & Question Wording \\
\hline Fed. Partisanship: Liberal & Partisanship & $\begin{array}{l}\text { In FEDERAL politics, do you usually think of yourself } \\
\text { as a: Liberal, Conservative, NDP, Green, Bloc, Other, } \\
\text { None of the Above, Don't know. (Selected Liberal with } \\
\text { "very" or "fairly" strong identity) }\end{array}$ \\
\hline Fed. Partisanship: NDP & Partisanship & $\begin{array}{l}\text { In FEDERAL politics, do you usually think of yourself } \\
\text { as a: Liberal, Conservative, NDP, Green, Bloc, Other, } \\
\text { None of the Above, Don't know. (Selected NDP with } \\
\text { "very" or "fairly" strong identity) }\end{array}$ \\
\hline Fed. Partisanship: None & Partisanship & $\begin{array}{l}\text { In FEDERAL politics, do you usually think of yourself } \\
\text { as a: Liberal, Conservative, NDP, Green, Bloc, Other, } \\
\text { None of the Above, Don't know. (Selected none of the } \\
\text { above, don't know, or identify "not very strongly") }\end{array}$ \\
\hline Prov. Partisanship: Green & Partisanship & $\begin{array}{l}\text { In PROVINCIAL politics, do you usually think of } \\
\text { yourself as a: Green, Liberal, NDP, Other, None of the } \\
\text { Above, Don't know. (Selected Green and identifies } \\
\text { "very" or "fairly" strongly) }\end{array}$ \\
\hline Prov. Partisanship: Liberal & Partisanship & $\begin{array}{l}\text { In PROVINCIAL politics, do you usually think of } \\
\text { yourself as a: Green, Liberal, NDP, Other, None of the } \\
\text { Above, Don't know. (Selected Liberal and identifies } \\
\text { "very" or "fairly" strongly) }\end{array}$ \\
\hline Prov. Partisanship: NDP & Partisanship & $\begin{array}{l}\text { In PROVINCIAL politics, do you usually think of } \\
\text { yourself as a: Green, Liberal, NDP, Other, None of the } \\
\text { Above, Don't know. (Selected NDP and identifies "very" } \\
\text { or "fairly" strongly) }\end{array}$ \\
\hline Prov. Partisanship: None & Partisanship & $\begin{array}{l}\text { In PROVINCIAL politics, do you usually think of } \\
\text { yourself as a: Green, Liberal, NDP, Other, None of the } \\
\text { Above, Don't know. (Selected none of the above, don't } \\
\text { know, or identify "not very strongly") }\end{array}$ \\
\hline Satisfaction: Council & Retrospec. & $\begin{array}{l}\text { How satisfied are you with the performance of: the } \\
\text { current city council }\end{array}$ \\
\hline Satisfaction: Mayor & Retrospec. & $\begin{array}{l}\text { How satisfied are you with the performance of: the } \\
\text { current mayor }\end{array}$ \\
\hline Satisfaction: Federal & Retrospec. & $\begin{array}{l}\text { How satisfied are you with the performance of: The } \\
\text { federal government }\end{array}$ \\
\hline Satisfaction: Province & Retrospec. & $\begin{array}{l}\text { How satisfied are you with the performance of: the } \\
\text { provincial government in B.C. }\end{array}$ \\
\hline Economy: Provincial & Retrospec. & $\begin{array}{l}\text { Over the past year has the economy in the following } \\
\text { places gotten better, gotten worse, or stayed about the }\end{array}$ \\
\hline
\end{tabular}




\begin{tabular}{|c|c|c|}
\hline Variable & Category & Question Wording \\
\hline Economy: Federal & Retrospec. & $\begin{array}{l}\text { Over the past year has the economy in the following } \\
\text { places gotten better, gotten worse, or stayed about the } \\
\text { same? Canada }\end{array}$ \\
\hline Economy: Municipal & Retrospec. & $\begin{array}{l}\text { Over the past year has the economy in the following } \\
\text { places gotten better, gotten worse, or stayed about the } \\
\text { same? Vancouver }\end{array}$ \\
\hline Woman & Socio-Demographics & $\begin{array}{l}\text { Are you: male, female, other/gender non-binary, prefer } \\
\text { not to say }\end{array}$ \\
\hline Duration in Municipality & Socio-Demographics & How long have you lived in Vancouver? \\
\hline Age & Socio-Demographics & In what year were you born? \\
\hline Home Owner & Socio-Demographics & Today, are you the owner of: your primary residence? \\
\hline Immigrant & Socio-Demographics & Were you born in Canada? \\
\hline University Degree & Socio-Demographics & $\begin{array}{l}\text { What is the highest level of education that you have } \\
\text { completed? (Bachelors degree or higher coded as } 1 \text { ) }\end{array}$ \\
\hline Income & Socio-Demographics & $\begin{array}{l}\text { Which of the following best indicates your annual } \\
\text { household income before taxes? }\end{array}$ \\
\hline
\end{tabular}

